\title{
THE INTERACTION OF CLIMATE CHANGE AND AGENCY IN THE COLLAPSE OF CIVILIZATIONS ca. 2300-2000 BC
}

\author{
MALCOLM H. WIENER
}

Institute for Aegean Prehistory, 66 Vista Drive, Greenwich, CT 06830, USA. Corresponding author: mhwiener@villacandia.com.

\section{ABSTRACT}

\begin{abstract}
Human history has been marked by major episodes of climate change and human response, sometimes accompanied by independent innovations. In the Bronze Age, the sequencing of causes and reactions is dependent in part on dendrochronology and radiocarbon dating. This paper explores the interaction of a major, prolonged desiccation event between ca. 2300 and $2000 \mathrm{BC}$ and human agency including migrations, the displacement of trading networks, warfare, the appearance of weapons made of bronze, and the first appearance of sailing vessels in the Mediterranean.
\end{abstract}

Keywords: archaeological science, civilizational collapse, climate, 4.2 ka cal BP event, Early Bronze Age in Aegean, Anatolia, Crete, Cyclades, Greece, Egypt, Levant.

\section{INTRODUCTION}

Dendrochronology and radiocarbon dating together with texts, archaeological sequences, and astronomical observations and calculations, both ancient and modern, provide a framework for studying the human past. Examination of tree rings, soil conditions, archaeological evidence, and written records when available allows the identification of major climate events throughout history and prehistory. How societies respond to major climate events together with contemporary developments in other dimensions, including migrations, weapons and warfare, modes of transport, and plagues, determine societal survival or collapse. We begin with a brief summary of known or likely critical climate shifts impacting the history of humankind. This article seeks in particular to analyze the interactions between climate and human agency during what has been called the collapse of civilizations ca. 2300-2000 BC (a.k.a. the 4.2 ka cal BP event).

\section{SYNOPSIS OF CLIMATE EVENT SEQUENCE}

Climate events with dramatic consequences have occurred throughout history (Weiss and Bradley 2001). A second collapse of civilizations in Anatolia, the Eastern and Central Mediterranean occurred at the end of the Bronze Age in the 12th and 11th centuries BC, about 1000 years after the $4.2 \mathrm{ka}$ cal BP event. Dryness and drought in some areas, episodes of plague and epidemics, widespread and repeated warfare, major migrations of peoples, earthquakes at critical moments and places, and/or complex systems failure have been proposed as causes of the collapse, or of one of two stages of the collapse, ca. 1200 and ca. 1120-1080 BC (see generally Yasur-Landau 2010; Aegean: Dickinson 2006: esp. 43-57, and works cited therein; Egypt: Goedicke 1984; Ritner 2000:111-112; Anatolia: Bryce 1998:223-225; Biblical accounts: Exodus 9:1-12; 1 Samuel 5:9-12; Freemon 2005 interprets events described in 1 Samuel as plague; Wiener, forthcoming).
Adverse climate is believed to have played a major role in the Hun and Avar migrations into the western Roman Empire in the 4th, 5th, and 6th centuries AD and its demise over the course of the 5th-7th centuries AD (Cook 2013:90-91; McCormick 2013; Zwickel 2012 places a severe drought in the southern Levant in 445-433 BC). In the case of the decline of the Roman Empire, we are again confronted with the question of the relative importance of climate change versus plague and of their possible near-simultaneous occurrence, and particularly with regard to the significance of diminished food supplies in reducing resistance to plague (Ruddiman 2005:52). Epidemics were frequent during the Roman Empire, most notably the Antonine plague of AD 160 165 , recurring in $\mathrm{AD} 189$, and the plague of Justinian beginning in AD 542. Both the Antonine and Justinianic plagues resulted in death tolls for the Roman world similar in proportion to those from the Black Death for all of Europe (Paine 2000:188). DNA analysis has shown the Justinianic plague to be identical to the bubonic plague that ravaged Europe in AD 1347-1351 (Harbeck et al. 2013).

Devastating droughts in the Eastern Mediterranean from AD 950 to 1072, at times extending to modern Iraq and Iran, are reported (Ellenblum 2012). The Ellenblum study includes two points of general interest: (1) that unusually cold weather in the northern part of the zone studied played as great a role in the destruction of crops as lack of rainfall; and (2) that the dry period was not continuous, but rather was interrupted with years of normal rainfall, which however proved insufficient in number to arrest the overall decline. Both the Medieval Warm Period of the 10th-13th centuries AD (Diaz et al. 2011) and the Little Ice Age of the 16th-18th centuries (Grove 1988) are well established, with their attendant consequences. Beginning in AD 1590 and extending for more than a century, the impact of the Little Ice Age in Europe was dramatic. Peaks are reported ca. AD 1590 and 1690. In Crete, the peaks were accompanied by famine and the outbreak

Center for Mediterranean Archaeology and the Environment (CMATE) Special Issue

Joint publication of Radiocarbon and Tree-Ring Research 


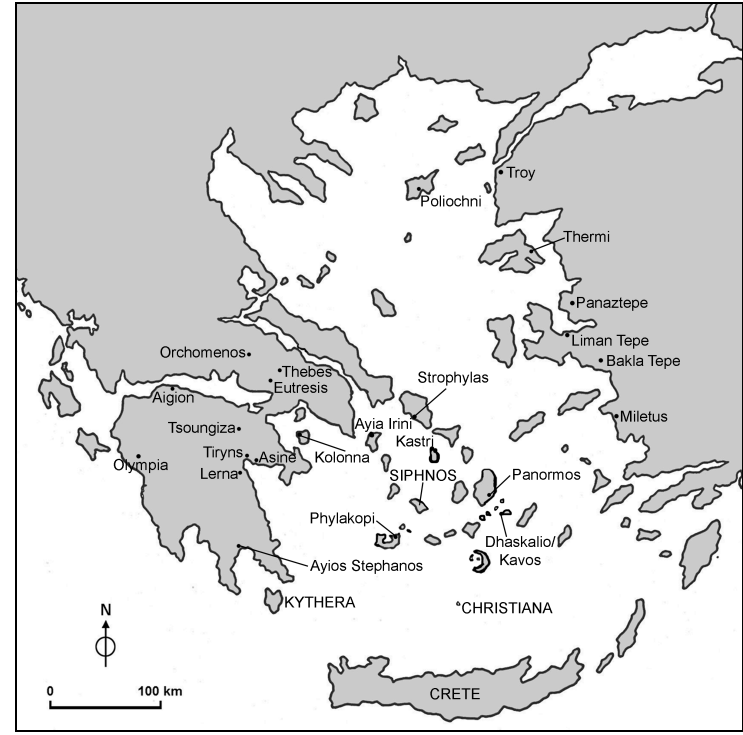

Figure 1a. Map of the Aegean, showing sites mentioned in the text.

of plague (Rackham and Moody 1996:39-41). Le Roy Ladurie has observed that the loss of over a million people in France in the decade between AD 1691 and 1701 equaled the losses in World War I, but in a population that numbered 20 million rather than 40. Those males who survived the famines were stunted, "reaching an average height of only 5 feet - among the shortest Frenchmen ever recorded" (Parker 2013:589). Social upheaval was reported from around the world, resulting in the premature death of around one-third of the human population (Parker 2013). Three potential causative factors have been proposed: (1) an unusually large number of volcanic eruptions in the period, (2) double the usual number of warm ocean water El Niño episodes along the west coast of South America, and (3) a marked decrease in sunspot activity reducing solar output (Parker 2013:587).

Studies of the impact of climate change on societies began earlier and are further advanced in the Americas than in the Old World. Linkage between climate stress, warfare, and collapse has been argued in particular with regard to the end of Mayan civilization, where there is evidence of droughts and megadroughts at various times and locations (deMenocal 2001:670), and in some cases the possibility exists for annual comparisons between drought effects on datable tree rings and datable texts describing wars (Aimers and Hodell 2011; Kennett et al. 2012; MedinaElizalde and Rohling 2012). Tree-ring records indicate that drought may have been a prime factor in the uprooting of the Anasazi in the American Southwest ca. 800 years ago (Larson et al. 1996). Climate stress has been proposed as a critical factor in other cases of societal collapse in the Southwest as well, for example the Chacoan collapse of the 11th century AD (Herr and Clark 1997:382). The loss of the first colony of English settlers in the New World, who arrived at Roanoke, Virginia, in AD 1587, has been attributed to a devastating drought between AD 1572 and 1593 (deMenocal 2001:668).

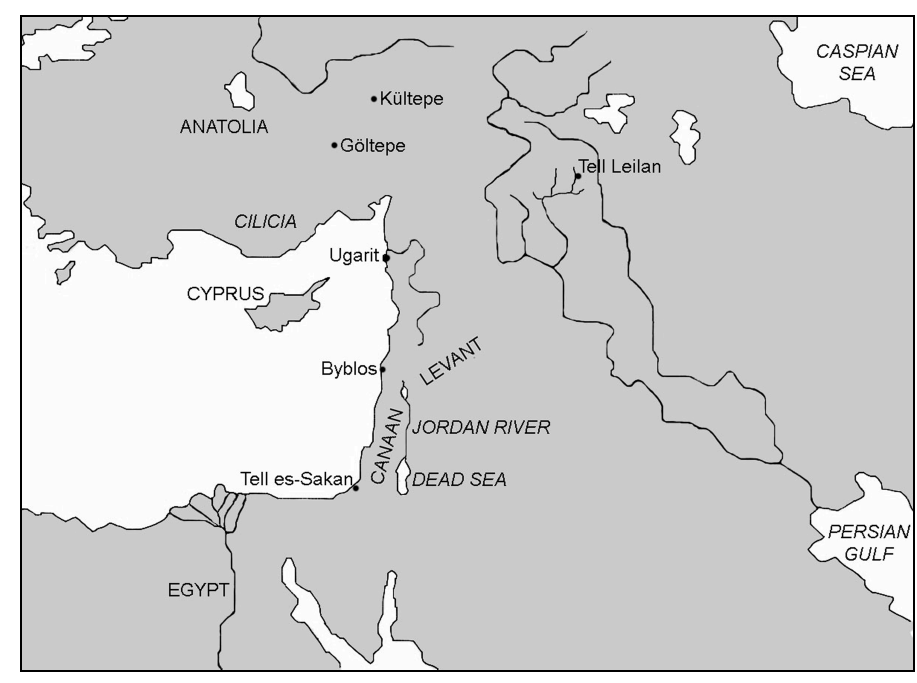

Figure 1b. Map of the Near East, showing sites mentioned in the text.

Ironically, it appears that in at least one instance a period of benign climate facilitated a wave of devastation. Examination of tree rings of Siberian pines in central Mongolia indicates a period between AD 1211 and 1225 of sustained rainfall and mild weather, which coincides precisely with the dramatic rise of the Mongol Empire of Genghis Khan. Pastures rich after a preceding drought provided fodder for the herds of war horses on which the Mongol armies depended and enabled them to conquer lands from China to Hungary. Higher grass yields may also have provided fodder for a greater number of camels, yaks, cattle, and sheep for the invaders (Pederson et al. 2014). Apparently people move and sometimes pillage not only when they must, but also when they can.

The impact of climate change depends, inter alia, on the severity and extent of the event, its effect on food supplies (or what in population biology studies is called the carrying capacity of the environment), whether the society experiences simultaneous outbreaks of plague (whose effects may be exacerbated by food shortages), the nature of concomitant or resulting societal changes with regard to migration and/or warfare, and the fragility or resilience of the society and other societies to which it is closely linked. Study of the interaction of climate change and human agency presents many challenges, but is essential to progress in understanding the history of humanity.

\section{THE NATURE AND EXTENT OF THE PROPOSED CLIMATE EVENT OF ca. 2300-2000 BC}

The underlying nature and cause of the proposed $4.2 \mathrm{ka}$ cal BP climate event is thus far unclear. A number of climatologists, concentrating on evidence from the Near East and the Mediterranean (see Figure 1 for maps of the discussed sites and Figure 2 for the relative chronology for the studied area), believe that the moistureladen North Atlantic cyclonic westerly winds, which seasonally break into the Mediterranean trough and provide the winter precipitation needed for dry farming, failed for reasons still unknown, 


\begin{tabular}{|c|c|c|c|c|c|c|}
\hline $\begin{array}{c}\text { Greek } \\
\text { Mainland }\end{array}$ & Crete & Cyclades & Troy & Egypt & $\begin{array}{c}\text { Syria / } \\
\text { Palestine }\end{array}$ & $\begin{array}{c}\text { Northern } \\
\text { Mesopotamia }\end{array}$ \\
\hline $\begin{array}{c}\text { Early } \\
\text { Helladic I }\end{array}$ & $\begin{array}{c}\text { Early } \\
\text { Minoan IA } \\
\text { Early } \\
\text { Minoan IB }\end{array}$ & $\begin{array}{c}\text { Early } \\
\text { Cycladic I }\end{array}$ & $\begin{array}{c}\text { Troy } \\
\text { I }\end{array}$ & \multirow{3}{*}{$\begin{array}{c}\text { Old } \\
\text { Kingdom }\end{array}$} & \multirow{3}{*}{$\begin{array}{c}\text { Early } \\
\text { Bronze III }\end{array}$} & \\
\hline \multirow{2}{*}{$\begin{array}{c}\text { Early } \\
\text { Helladic II }\end{array}$} & $\begin{array}{l}\text { Early } \\
\text { Minoan } \\
\text { IIA }\end{array}$ & \multirow{2}{*}{$\begin{array}{c}\text { Early } \\
\text { Cycladic II }\end{array}$} & $\begin{array}{c}\text { Troy } \\
\text { II }\end{array}$ & & & Leilan IIId \\
\hline & $\begin{array}{l}\text { Early } \\
\text { Minoan } \\
\text { IIB }\end{array}$ & & $\begin{array}{c}\text { Troy } \\
\text { III }\end{array}$ & & & $\begin{array}{l}\text { Leilan IIb } \\
\text { Leilan IIa }\end{array}$ \\
\hline $\begin{array}{c}\text { Early } \\
\text { Helladic III }\end{array}$ & $\begin{array}{c}\text { Early } \\
\text { Minoan III }\end{array}$ & $\begin{array}{c}\text { Early } \\
\text { Cycladic } \\
\text { III } \\
\end{array}$ & $\begin{array}{c}\text { Troy } \\
\text { IV }\end{array}$ & \multirow{3}{*}{ F.I.P. } & \multirow{2}{*}{$\begin{array}{c}\text { Early } \\
\text { Bronze IV }\end{array}$} & \multirow{3}{*}{$\begin{array}{l}\text { "17 kings who wo } \\
\text { lived in tents" } \\
\text { Taya VI }\end{array}$} \\
\hline \multirow{5}{*}{$\begin{array}{l}\text { Middle } \\
\text { Helladic }\end{array}$} & \begin{tabular}{|c|} 
Middle \\
Minoan IA \\
\end{tabular} & \multirow{5}{*}{$\begin{array}{l}\text { Middle } \\
\text { Cycladic }\end{array}$} & \multirow{2}{*}{$\begin{array}{c}\text { Troy } \\
\text { V }\end{array}$} & & & \\
\hline & \begin{tabular}{|c|} 
Middle \\
Minoan IB
\end{tabular} & & & & $\begin{array}{l}\text { Middle } \\
\text { Bronze I }\end{array}$ & \\
\hline & $\begin{array}{l}\text { Middle } \\
\text { Minoan } \\
\text { IIA }\end{array}$ & & \multirow{3}{*}{$\begin{array}{c}\text { Troy } \\
\text { VI }\end{array}$} & \multirow{3}{*}{$\begin{array}{c}\text { Middle } \\
\text { Kingdom }\end{array}$} & \multirow{2}{*}{$\begin{array}{c}\text { Middle } \\
\text { Bronze IIA }\end{array}$} & \multirow{3}{*}{ Leilan I } \\
\hline & $\begin{array}{l}\text { Middle } \\
\text { Minoan } \\
\text { IIB }\end{array}$ & & & & & \\
\hline & $\begin{array}{c}\text { Middle } \\
\text { Minoan III }\end{array}$ & & & & $\begin{array}{c}\text { Middle } \\
\text { Bronze IIB }\end{array}$ & \\
\hline
\end{tabular}

Figure 2. Relative chronologies of the regions discussed.

and that 250 years later westerlies-borne precipitation returned to pre-aridification levels (Weiss 2012). A number of recent studies, however, point to a Northern Hemisphere-wide megadrought event at $4.2 \mathrm{ka}$ cal BP (Magny et al. 2009; Triantaphyllou et al. 2009; Walker et al. 2012:654, and citations therein); for example, it is proposed that the dramatic changes in the Apennines about this time are contemporaneous with an ice sheet-fracture event in the North Atlantic (Drysdale et al. 2006; Giraudi et al. 2011:112). In the mountain ranges of Arizona and California, high-elevation tree samples virtually disappear ca. 2140-1800 BC, with a largescale event in 2036 BC (M. Salzer, personal communication, 5 September 2013). Similar results are reported for other areas (Salzer et al. 2014). The collapse of Neolithic cultures in China has been associated with a climate event at this time by a number of scholars (Wang et al. 2005, and references therein). Following a marked mid-3rd millennium $\mathrm{BC}$ expansion in site size and complexity, a climate event indicated by far lower lake levels and other evidence is suggested by some in the following period beginning between 2200 and $2000 \mathrm{BC}$, with settlers leaving central China and the Yellow River alluvium and moving south to the Yangtze, connected to what appears to be a major regression of the Yangtze River Civilization (Wenxiang and Tungsheng 2004; Yancheva et al. 2007:76). Yasuda (2013:50) adds that those moving south likely included pastoral peoples wielding metal weapons. At the end of the 3rd millennium BC, many of the large Neolithic sites ceased to exist, following which a few-most notably Erlitou, which gave its name to the culture and was later believed to be the capital of the Xia Dynasty - emerged as regional centers (Shelach 2012). Three main categories of drivers are suggested for a putative Northern Hemisphere-wide event: "1) internal instability of the Greenland Ice Sheet or Arctic sea ice; 2) ocean oscillator and the bipolar seesaw; 3) North Atlantic changes forced by solar variations" (Fisher et al. 2008:675).
Others suggest a still broader event, observed in more than 30 paleoclimate proxies from Tanzania in Africa to Rajasthan in India (Staubwasser and Weiss 2006; Arrivabeni 2012; Weiss 2013, and works cited therein), possibly involving a change in solar irradiance or a succession of major volcanic eruptions. One major study states that "the evidence increasingly suggests a link between changes in solar activity and significant episodes of climate change on earth (especially, the increases in radiocarbon production corresponding to marked cooling periods)" (McCormick et al. 2012:211, citing numerous papers; see also Eddy 1976, 1977; Magny 1993). Lakes in the vicinity of Mt. Kilimanjaro $4^{\circ}$ below the Equator in Africa experience water level decreases at this time (Thompson et al. 2002). A worldwide megadrought at ca. 2200 BC is proposed by Booth et al. (2005). There is, however, no evidence of climate change in the Greenland ice cores or in the highresolution stalagmite from Sofular on the Black Sea coast, leading Weninger (2014) to suggest a mid-northern-latitude boundary to the $4.2 \mathrm{ka}$ cal BP event. (Of course, areas north of the putative climate-event boundary may have experienced a major impact from migrations or other consequences of the climate event.)

\section{CONSEQUENCES OF THE 4.2 ka CAL BP EVENT IN THE EASTERN MEDITERRANEAN}

The period ca. 2300-2000 BC in the Near East saw the collapse of the Akkadian Empire around 2150 BC (Yoffee 1988:46-49; Cooper 2006:18-19) and its shorter-lived successor, the Third Dynasty of Ur (ca. 2100-2000 BC), with the once great capital city of Ur overrun by invaders from the north, as human groups moved south along the Euphrates River valley seeking food and pasturage (Weiss and Courty 1993:144; Cooper 2006:19). In Western Asia, the pattern of devastation beginning 2300-2250 BC is uneven, however, with the severity and chronology differing between areas (Mayewski et al. 2004; Riehl 2008, 2009; Rambeau and Black 2011:98). Coastal sites receive more rain than inland sites, and sites to the north of $36^{\circ}$ latitude and the modern $300-\mathrm{mm}$ isohyets received more rain than sites further south, such as Qatna and Emar (Riehl et al. 2014:3). In general, the pattern inland is one of abandonment of areas dependent on rain or variable streams and an increase in the number of sites and population along the banks of major rivers, or perhaps in some cases in areas of marsh or adequate spring water (Peltenburg 2007; Weiss 2013). For example, Mari on the Euphrates and Tell Brak on the Khabur River appear to continue to thrive (Akkermans and Schwartz 2003:254). In many areas, however, "societies responded to the abrupt climate change with political collapse, regional abandonment, nomadization, and habitat-tracking to sustainable agricultural regions" (Weiss 2013). (Doubts concerning the impact and extent of the putative climate event are expressed in Koliński [2007], Ur [2010b:157], McAnany and Yoffee [2010], Finné et al. [2011], and Middleton [2012].) Wilkinson (1994) stresses his Brittle Economy Model as playing a critical role in discussing the collapse. Butzer, while accepting a "dry shift" involving a substantial decrease in precipitation as indicated by fluctuations in 
the water levels of Lake Van in eastern Turkey and Lake Zeribar in western Iran (Butzer 1995:136-138, Figure 2; see also Matthews 2002), proposes that various factors including continuing Akkadian aggression and demands plus resistance resulting in continuing warfare played important roles in the collapse in the Near East and that the end of Byblos with its Egyptian emporium had a major role in weakening the Old Kingdom in Egypt (Butzer 2012:3633-3634). Of course, a major desiccation event even in one critical area that sets a population in motion and interrupts a trade network for essential imports can provide cascading effects including warfare (Hsiang et al. 2013). Network theory asserts that the more interconnected the whole, the more likely that local losses will be repaired when they occur until a critical stress level is reached, at which point the entire system will collapse (Perrow 1999; Scheffer et al. 2012).

In Anatolia, the arc of destruction includes Troy, where the great walls of Troy II-III (ca. 2550-2200 BC) fall into ruin and Troy late III-V (ca. 2200-1900 BC) and in particular Troy IV, suffer six destruction levels, while the inhabited area shrinks drastically; surrounding smaller sites disappear along with evidence of external contacts; signs of stress on barley crops appear; and faunal remains indicate an altered diet containing a significant percentage of deer and other non-domesticates (Pavúk et al., forthcoming). Drought affects livestock along with crop supplies, of course. Recently (AD 2006-2009), herders in eastern Syria were reported to have lost around $80 \%$ of their livestock due to drought (Erian et al. 2010; Sohl 2010). Moreover, pest outbreaks in mid-latitude agro-ecosystems are often associated with warm, dry weather, and many insects are migratory (Porter et al. 1991). Weninger (2014) believes that Troy was in essence abandoned for a period of 100-200 years between Troy III and Troy IV, beginning ca. $2150 \pm 30$ cal years BC.

Sites on the Anatolian coast south of Troy undergo major change as well. Kouka summarizes the evidence as follows:

The strong interaction between powerful early urban settlements of the late EB [Early Bronze] II and early EB IIIA led to serious sociopolitical changes in EB IIIB, as suggested by the decline of the once strong centers in western Anatolia (Troy II, Liman Tepe) and by the contraction of the Anatolian trade network (Kouka 2013:577).

In the Early Bronze II period (preceding the end of Early Bronze II-III destructions and abandonments ca. 2300-2000 BC), the site of Liman Tepe, on the north coast of the peninsula west of Smyrna (modern Izmir in Turkey), undergoes a major reorganization including the establishment of a new monumental fortification system with horseshoe-shaped bastions, but that at the end of the period it too suffers a major destruction marked by a severe fire and a total reorganization on a new plan (Şahoğlu 2008:488-490). Farther south along the Turkish coast, at the port site of Tavşan Adasi north of Didyma, a hiatus in occupation after Early Bronze II-III has been reported (Bertemes 2011). Sites in Cilicia and in the central Taurus mountain range, such as the major metallurgical site of the Kestel mines and the adjacent 65-ha site of Göltepe located $80 \mathrm{~km}$ north of Tarsus (Yener 1995; see also Muhly 1993; Yener and Vandiver 1993a, 1993b), and to the east across the Taurus range at Kültepe, are abandoned. Conditions at Kültepe in central Anatolia may have improved by ca. 2027-2024 BC, the date proposed by dendrochronological analysis for the construction of the major structure called the Old Palace (Barjamovic 2012). Norşuntepe in east-central Anatolia also appears to possess a functioning significant administrative complex in this period (Hauptmann 1976).

In the Habur Valley in northeastern Syria, a number of major Akkadian sites such as Tell Leilan are buried in dust and abandoned ca. 2250-2220 BC (Weiss et al. 1993). Many other Syrian sites are abandoned early in Early Bronze IVB, with the final wave of destruction and abandonment coming at the end of Early Bronze IVB, around the end of the 3rd millennium (Porter 2007; Schwartz 2007:52; Ur 2010a:388, 412). A recent proposal to move the horizon earlier by about 3 centuries based on a number of radiocarbon determinations (Regev et al. 2012a, 2012b) appears unwarranted by the totality of the evidence (Schwartz et al. 2012; Bietak 2013: esp. 94). The excavators of Umm el-Marra in western Syria report a hiatus of several centuries (Schwartz et al. 2012:179). Some of the people set in motion headed south toward river-land, to judge from texts reporting that a 180-kilometer-long wall called the "Repeller of the Amorites" was built across the center of Mesopotamia to limit nomadic incursions (deMenocal 2001:669). Another long wall, the Très Long Mur, was built to protect "the new karstic-spring Orontes River urban refugia from ‘Amorite' nomad incursions" (Weiss 2012:13).

In Canaan, a decrease in rainfall beginning around $2300 \mathrm{BC}$, and resulting in the creation of the wadis visible today, has been proposed as the cause of the precipitous decline in the number of inhabited sites in Early Bronze III-IVB (Mazar 1990:151-173; Falconer 1994; de Miroschedji 2010), including the hiatus posited at the major site of Ugarit (Astour 2002:165-166), which appears to have been abandoned for a century, and perhaps two (Yon 2006:16). In the Intermediate Bronze Age, the Early Bronze Age urban centers in Canaan in general and the Judean Highlands in particular were abandoned, with parts of the population reverting to pastoralism (Langgut et al. 2014:14, and works cited therein. Genesis [12:10] states that famine drove Abraham to Egypt). West of the Jordan and the Dead Sea, not a single site has been found that survived the collapse. A few sites survived in the stream-fed northern Levant (Gophna and Portugali 1988; de Miroschedji 2010).

Of course, the severity and duration of any climate event in a particular locality will depend on a number of factors, including the climate zone in which the site is situated-e.g. North Atlantic cyclonic westerlies vs. Cyprus cyclones-local soil and insect conditions, and human responses to crises. Roberts et al. (2011:153) propose on the basis of carbon isotope analysis that 
in northern Syria water crises occurred during the period 22002050 BC. Schwartz (2007) believes that the decline in the number of settlements in northern Syria may have occurred at slightly different times in different places while others suggest two separate phases of degeneration, one ca. 2300-2200 BC and the other ca. 2000-1900 BC (Koliński 2007; Pfälzner 2012). Finkelstein and Langgut (2014) suggest that the movement of the precursors of the Hyksos from the Levant to the Nile Delta ca. 1900 BC described in Egyptian sources may be connected to the climate event. In Cyprus, the Philia phase of the Early Bronze Age, characterized by a uniformity of material culture indicating close connections between different parts of the island (Webb and Frankel 1999; Frankel and Webb 2012:1380) and linked to a broader Eastern Mediterranean interaction sphere, breaks down ca. 2200 BC, perhaps responding to the general collapse of overseas systems rather than, or in addition to, climatic factors (Frankel and Webb 2012:1380; Manning 2013).

In Egypt, the incidence of famine increases in the late Sixth Dynasty as Nile levels fall, reaching a minimum ca. 2200-2100 BC (Bell 1971; Redford 1992:61-62; Bard 2008:163; Touzeau et al. 2013) as the Old Kingdom begins its collapse into the chaos of the First Intermediate Period. Strontium isotopic and petrological information obtained from sediment cores collected in the Nile Delta are reported to show that paleoclimatic and Nile baseflow conditions changed considerably from about 4.2 to $4.0 \mathrm{ka}$ cal BP, resulting from a decrease in vegetative cover accompanying a marked decline in rainfall (Stanley et al. 2003). At Saqqara, the site of the Step Pyramid near the Old Kingdom capital at Memphis, a type of beetle adapted to extremely dry climates makes its initial appearance (Rosen 2007:144-149, cited in Broodbank 2013a:348). The autobiography of Ankhtifi, a southern provincial governor of the Ninth Dynasty ca. 2100 BC, inscribed on a rockcut tomb, reports starvation caused by Nile failure, dislocation, and the breakdown of order (Butzer 2012:3633). "The river of Egypt is empty, men cross over the water on foot," says the text (Bell 1971:17).

Greece in general receives more rain than the Near East or Egypt, but its mountainous nature makes it highly "sensitive to even small changes in the atmospheric circulation over the Eastern Mediterranean" (Mariolopoulos 1938:370; Donley 1971; Zerefos and Zerefos 1978:299). In periods of dryness, the west-facing valleys of Achaea fare better than Laconia and Messenia, for example (regarding the Late Bronze Age, see, e.g. Carpenter 1966:37, 63; O'Brien 2013:15). In Laconia, the site of Ayios Stephanos near the southern coast of the Peloponnese is abandoned toward the end of Early Helladic II and not reoccupied until the Middle Helladic period beginning ca. 2000 BC (Hope Simpson and Janko 2011:99). It is worth noting, however, that the mining and processing of silver apparently continues at the mines at LavrionThorikos in Attica (Spitaels 1984; Nakou 2007:235), though perhaps under new auspices. There is some evidence for dryness elsewhere in the Peloponnese and other parts of Greece in the late 3rd millennium BC. The Early Helladic IIC-D period in the Argolid is marked by the appearance of what is known as the Pikrodafni alluvium, caused either by a severe dry period or possibly by catastrophic summer rains causing major soil erosion (Van Andel et al. 1986: esp. 113). Evidence of soil erosion has been identified at the site of Markiani on the island of Amorgos in the Cyclades (French and Whitelaw 1999). Gejvall notes that the desiccation hypothesis is supported by the appearance at Lerna in Early Helladic III of types of birds that can exist only in a climate significantly drier than the present (Gejvall 1969:47-49, 55). At Olympia in the western Peloponnese, the end of Early Helladic II and especially Early Helladic III sees the Early Helladic II habitation and burial zones covered by alluvial deposits of the Alpheios and Kladeos rivers (Giannopoulos 2012:243-244, with references), which change courses, while at the same time cultural displacement is indicated by the appearance of Cetina culture elements originating in the Balkans (see below).

There is, however, a longstanding question regarding cause and effect, with some contending that increasing population and the absence of land and crop rotation led to serious soil erosion and a reduced carrying capacity of land. In this regard, I believe that Bintliff, the leading authority on land use and animal husbandry in ancient Greece, is correct in stating that

the oldest general Holocene episode, late Early Bronze Age locally, is our first example where complex societies collapse in the South Aegean. Dense and widespread settlements on the Mainland are then replaced by low density communities. Around this era serious erosion is indicated. It has been claimed that overpopulation led to soil loss, but it is difficult not to attribute a role too to the well-known $2200 \mathrm{BC}$ phase of aridity in the Eastern Mediterranean. I would be more inclined to suggest that a landscape pre-adapted to erosion by intensive land use was triggered into alluviation by a phase of extreme climate (Bintliff 2012:214).

Contemporary evidence from the Cyclades is lacking apart from the occurrence of soil erosion on Amorgos cited above. The islands today suffer frequent water shortages with great interyear variability. Major differences exist between islands, but none is entirely water sufficient in the long run (Gejvall 1969:47-49, 55; Van Andel et al. 1986:113; Broodbank 2000:77-78; Wilson 2008:98).

With respect to Crete, there is evidence for a shift to a hotter and drier climate during the transition from the Early Minoan to the Middle Minoan period including water stress (Rackham and Moody 1996:124-128; Moody 2009:243-245, 247, citing evidence of species shifts based on pollen records from two WestCretan land cores and a deep sea core; Betancourt 2012:130). Moody (2009:244) concludes that "summer evaporation soars to an interglacial high between c. 2200-2000 BC" (see also Bottema and Sarpaki 2003). East Crete is likely to have been more severely affected than the west and center of the island because the prevail- 
ing winds are from the west and the mountains separating west from central Crete block some rain from reaching the east (Ayia Varvara on the highest point of the road from Knossos to Phaistos is said by its inhabitants to experience rain 300 days of the year). Even West Crete may have been affected by climate change, however. The pollen record from Tersanas in northwestern Crete shows linden trees that grew during the Early Bronze Age declining in frequency in the Middle Bronze Age (Betancourt 2012:130, citing Clark 2004:31; see generally Rackham and Moody 1996:xvi and 123-126).

In the Aegean as in Western Asia, the pattern of destruction/ devastation is irregular, with the severity and chronology differing between areas. East Crete and the south-central coast suffered a number of destructions in or at the end of Early Minoan II (Watrous 2004:266-267; Wilson 2008:97; Nowicki 2013), but at some point in Early Minoan III at least the site of Palaikastro on the east coast of Crete recovered, if a building from this period described as massive is any indication (Cunningham 2012:64-65). Early Minoan III is a period of significant construction and increasing complexity at the major sites of Knossos, Phaistos, and Malia in central Crete as well. The Mesara Plain to the east of the Phaistos palace and of a high mountain range may have been slow to recover, however, which may explain in good measure the rapid and intense Phaistian settlement of the abundantly watered Amari Valley to the north following the consolidation of palatial authority at the beginning of the Old Palace Period beginning shortly after 2000 BC. At Kommos, the port of Phaistos located south of the palace, a layer of deep sand was encountered at the level that marked the beginning of the Middle Minoan period ca. 2000 BC (J. Wright, personal communication of 1 April 2013).

Throughout Crete today, interyear variation is high, with water availability dependent in good part both on the extent of the winter snowfall and whether it melts gradually or in torrents. Such variability may have intensified the need for major interyear social storage, which required in turn a more complex society. The destructions and abandonments in East Crete at the end of Early Minoan IIB immediately precede a period of marked increase in population and social complexity beginning sometime in Early Minoan III, as indicated by the impressive structures erected at the locations of what became the palaces of the Old Palace (a.k.a. the First Palace) Period at Knossos, Phaistos, and Malia, and by the tombs and tomb contents at Phourni Archanes above Knossos. In the end, whether mainland Greece, the Cyclades, or Crete were greatly affected directly by shortage of rain in Early Bronze III or suffered largely as a consequence of the migrations, new weapons technologies, the appearance of sailing vessels in the Aegean, or other factors, in part due to climate disaster in lands to the east and south, must remain an open question.

It is worth noting that in Early Bronze I-II prior to the postulated episode of climate change, the eastern shore of the Aegean led the western shore in site size, fortification walls, access to metal sources and trade networks, and social complexity. Troy, first excavated by Schliemann over a century ago, is but one of a series of large fortified citadels along the Anatolian coast and on the eastern Aegean islands at Poliochni, Thermi, Panaztepe, Liman Tepe, Bakla Tepe, and Miletus. Kouka (2013) notes that by ca. 3000 BC Liman Tepe already has long houses containing gold and silver jewelry and becomes a site of over 20 ha with a huge bastion when reorganized in Early Bronze II. Furthermore, the administrative use of seals and of common systems of weights over large areas begins in the Near East and travels west (Rahmstorf 2003, 2006a, 2006b, 2011). (A recent claim that in Early Bronze II "the northeastern Peloponnese appears to have been at the forefront of development in the Aegean" [Weiberg and Finné 2013:22] clearly only applies to the western shore of the Aegean and the Cyclades.) During Early Bronze I-II, Cycladic islanders in their longboats surely played a vital role in the transmission of goods, knowledge, and beliefs from east to west across the Aegean. The presence in the Cyclades in Early Bronze II of seals and sealings (Georgiadis 2012:188), as well as weights consistent with systems employed first in the east and then in Greece in Early Bronze II, are manifestations of this role. Rahmstorf (2003) suggests that the weights were principally employed in connection with the exchange of metals.

\section{Aegean Destructions and Abandonments}

In the Aegean, the "International Age" of Early Bronze II is followed by a period of turmoil (Forsén 1992:204-220, 255-256). On the Greek mainland, the massive Rundbau granary at Tiryns, and the substantial corridor houses at various sites, including the House of the Tiles at Lerna and the Weißes Haus at Kolonna on Aegina, are destroyed. The construction of corridor houses-major buildings with rectangular plans, front porches, flanking corridors, a number of large rooms, staircases leading to a second story, roof tiles, and in some cases lengths exceeding $50 \mathrm{~m}$-ends, along with the pre-state sealing administration system evident at Lerna, Geraki in Laconia, and other sites (Tiryns: Kilian 1986; Lerna: Dickinson 1994:189; Wiencke 2000:652-653; Geraki: Weingarten et al. 2011; various sites: Rahmstorf 2003:296). The southern Argolid region of the Peloponnese experiences a sudden dramatic decrease in the number of occupied sites from 26 to 3 in Early Helladic III around 2200 BC (Weiberg and Finné 2013). By the Middle Helladic/Middle Cycladic periods beginning around 2000 BC, evidence of seals and sealings disappears, metallurgy declines, and luxury goods practically disappear (Snodgrass 1971:383-386, 2006; Philippa-Touchais 2011). On the long island of Euboea just off the east coast of central Greece, a hiatus or decline in occupation of the Paximadi Peninsula has been described as "a very real possibility" (Cullen et al. 2013:101), based on limited excavation to date.

In the Cyclades, the manufacture of marble objects ceases or sharply declines and cist tomb burial ends (Broodbank 2000:177178, 322). Lead seals and clay seal impressions, such as those found in earlier strata at Markiani on Amorgos (Angelopoulou 2006), Aplomata on Naxos (Kontoleon 1972:151), and the Cave 
of Zas on Naxos (Zachos and Dousougli 2008) cease to appear. Fortifications are created on hilltops apparently for the purpose of protecting food supplies and people for limited periods in expectation of raids, for example at Kastri on Syros and Panormos on Naxos. At Panormos, the end was surely violent, to judge from the fact that the entrance was burnt and sling stones and a spearhead were found in the debris (Doumas 1992). Many Cycladic sites are abandoned, including the putative pan-Cycladic ritual center of Dhaskalio/Kavos on Keros (Renfrew et al. 2009, 2012).

At the Heraion on the island of Samos, the Zyklopischer Bau described by Kouka (2002:285-294, esp. 289) as the seat of the settlement chief ceases to exist, but the site continues with some evidence of communal feasting (Kouka 2013:576) and there is evidence of contact with central Anatolia, northern Syria, and the Aegean in Early Bronze III (Kouka 2002, 2013:577). There is no way of knowing whether in Early Bronze III between ca. 2300 and $2000 \mathrm{BC}$ such contacts were continuing or sporadic.

On the island of Kos in the Dodecanese, three sites in the northeast at Asklupis, Tsilimbiri, and Troulli appear to have been abandoned, with indications that the abandonments occurred toward the end of Early Bronze II. Eight sites in the center of the south coast of Kos also show no signs of occupation in the late Early Bronze II-III, with only the site of Koukos providing evidence for some occupation or reoccupation in Early Bronze III (Vitale 2013). Cycladic material ceases to appear at Helladic sites. The arc of upheaval extends farther west as well, for the temple culture of Malta and the metallurgical culture of Rio Tinto in Spain end ca. 2000 BC (Amzallag 2009:509; Broodbank 2013b). It is worth noting that the path of devastation appears to move from east to west over time, beginning in the Habur River Valley early in the 23 rd century BC.

During Early Minoan I and continuing into Early Minoan II, Cycladic material, both imported and locally made, appears at sites along the north coast of Crete (e.g. Ayia Photia, Gournes, Poros, Pyrgos Cave). Jars from the metalliferous islands of Melos, Siphnos, and Kea are prominent among the assemblages (Brogan 2013). The acquisition of metals was surely of prime importance to Minoans on Crete, who may have undertaken the requisite voyages. Brogan notes that a number of boat models were present in the excavated material from Early Minoan II Mochlos and suggests that the evident wealth including imported gold objects present may reflect an ability to launch sizable boats (Brogan 2013). West Crete exhibits a different pattern. There is little evidence of direct contact either with the rest of Crete or the Cyclades. Instead, alongside pottery of the local tradition, there appears in Early Minoan IIA a locally made black-slipped ware of HelladicCycladic shapes including sauceboats. The island of Kythera with its West Cretan-type settlement is a likely point of transmission. By Early Minoan IIB, such pottery no longer appears in West Crete (Nodarou 2011). Crete, and the northeast coast in particular, is not exempt from disturbance in Early Minoan IIB, as shown by the destruction at Mochlos, unexpected by the inhabitants it would seem (Brogan 2013); the massive perimeter walls erected at various sites in Early Minoan III (Watrous 2004:255; Watrous and Hadzi-Vallianou 2004:445); and the likely construction of harbor fortification walls at Malia at this time. Central Crete does not seem greatly affected, however, and before the end of Early Minoan III is well on the way toward state formation (Tomkins 2012), as indicated by the large-scale construction activity and the appearance of exotic foreign imports at Knossos, Archanes, Malia, and Phaistos. Todaro describes the "re-organization of the Phaistos hill at the beginning of the Early Minoan III period, in the course of a large building project that marked the beginning of the palatial phenomenon in south-central Crete" (S. Todaro, public communication of 15 March 2013).

Beginning in Early Bronze II in the northern Cyclades and central Greece, and continuing into Early Bronze III as far as Aegina and the southern Cyclades, metal forms, a ceremonial drinking kit, and burnished pottery of western Anatolian type including the much-discussed Kastri Group pottery appear, often in significant quantity (Broodbank 2000:309-319; Rutter 2008:469-470; Choleva 2012). Crete, however, is largely exempt from these developments. The cemetery at Ayia Photia on the northeast coast of Crete contains a small amount of Kastri Group pottery, dated to around the end of Early Minoan II/beginning of Early Minoan III (Davaras and Betancourt 2004:231-232), and a possible single sherd was reported from the fill of a Middle Minoan IA foundation deposit at Knossos (Hood 1971), but no other Kastri material has been reported from Crete. On the now-deserted island of Christiana, the closest of the Cyclades to Crete, however, Kastri Group depas handles and other sherds were visible on the surface of a saddle between two hills when several colleagues and I climbed to the location in 1998 (see also Sotirakopoulou 1993:16-17).

The boundary between the Cyclades and Crete marks an abrupt limit to the significant distribution of Kastri Group pottery and metallurgy. Pottery of the Phylakopi I type is also known from Christiana but infrequent in Crete, again indicating a line of demarcation. Eastern Adriatic Cetina culture objects that appear in mainland Greece at this time are also absent from Crete. Indeed, the first appearance of monumentality and literacy in the Aegean in Crete in Early Minoan III-Middle Minoan I may be the consequence of the fortunate position of Crete, just far enough apart and with sufficient population relative to size to resist destructive incursions, but within range of stimuli from the civilizations of Egypt and the Near East.

\section{THE PROCESS, CONTEXT, AND CONSEQUENCES OF COLLAPSE}

Fifty years ago, when I first began to study the Aegean Bronze Age, it was the general belief that this period, known as Early Helladic III, marked the arrival of a new people-indeed, the coming of the Greeks. Today, the prevailing view is different, in part because excavations in the intervening years have shown that the appearance of Kastri Group pottery and Anatolian metal 
forms preceded the destructions and in part because of the absence of an overall pattern, geographical or chronological, in the last half of the 3rd millennium BC in mainland Greece and the Cyclades. Destructions occur both at the beginning and end of Early Helladic III. In some cases, destructions are followed by gaps of centuries - one thinks, for example, of Ayia Irini on Kea, Tsoungiza in the Nemea Valley, or Aigion on the north coast of Achaia, or Geraki in Laconia, abandoned after a fierce fire in Early Helladic IIB (Papazoglou-Manioudaki 2010:131; Weingarten et al. 2011). Almost no Early Helladic III pottery has been identified from Laconia (Cavanagh and Mee 2011). At Lerna, the destruction of the House of the Tiles appears to be followed by immediate reoccupation of the site, but of a different nature, while at Thebes, Orchomenos and Eutresis in Boeotia, and at Tiryns in the Argolid, there is no apparent break in occupation but rather evidence of site reorganization. We should note, however, a number of highly significant changes in behaviors in southern Greece in Early Helladic III with antecedents in Anatolia. For example, Rutter, noting the appearance of a "radically different ceramic assemblage" including the appearance of a large-sized communal drinking vessel very similar to ones from Lycia on the Turkish coast, suggests that a new form of drinking behavior "may have diffused from Anatolia to Greece at the same time as did numerous other novel [ceramic] features...including shapes, the earliest use of the potter's wheel, and a marked preference for burnished surfaces" (Rutter 2008:461). Further, "the dramatic difference between the Early Helladic II and III repertoires of cooking pottery suggest that a shift in the manner of food preparation, possibly signaling a change in diet as well, may have been a facet of this cultural transition" (Rutter 2001:116). Van de Moortel carries the argument further, stating that the many changes in architecture, pottery, technology (including in particular a major advance in boat-building), and the daily habits of people that (as argued by Bourdieu [1977, 1990] and Giddens [1984]) are slow to change can only be explained by the arrival of a new people from the east and north, principally from Anatolia. The movement proposed should not be imagined as a single destructive wave, but rather as an influx over more than a century, violent in places and peaceful in others, resulting in a melding of populations (Van de Moortel 2013).

Of the new technologies introduced, Van de Moortel calls attention in particular to the likely introduction of the expanded longboat with a round hull, as depicted on two pots (an Early Helladic II Boeotian askos from Orchomenos and pottery fragments from Phylakopi I) and on Lefkandi I type vases from the island of Euboea off the east coast of central Greece. (An actual example of the outline of such a boat was excavated by Van de Moortel in a later context at the site of Mitrou opposite Euboea.) Van de Moortel believes that such faster, lighter boats would have permitted raiders from Anatolia to make unexpected attacks and land armed men, in the manner of the later Vikings. (The simultaneous advances in metallurgy and hence weapons are considered below.) It is even possible that a series of voyages by such improved longboats engaging in "down-the-line trade" (Renfrew 1975, 1977) were responsible for the appearance at Tiryns in the Argolid of Greece of a jar fragment characteristic of the Early Bronze IV repertoire of Canaan, which clay analysis suggests was made in central Palestine, while down-the-line voyages in the reverse direction may explain the appearance in Early Bronze IV tombs in northern Israel of vessels (askoi) of a shape typical of the Argolid (Oren 2003). Alternatively, the exchange of these vessel types and designs may be due to an early appearance of sailing vessels in the Aegean as discussed below.

The maintenance or resumption of trans-Aegean contacts during what is known as the Phylakopi I culture of the Early Bronze III-Middle Bronze I period following the destructions is indicated by the appearance at various sites of the "duck vases," used as containers for liquids, manufactured on the island of Aegina in the Saronic Gulf of Greece, on sites in the Cyclades, and on the island of Samos in the eastern Aegean and distributed in the northern and central Aegean but absent from Crete (Broodbank 2000:351-353).

Kolonna on Aegina is of special interest, for it appears on at least one occasion to receive jewelry from the Eastern Mediterranean during Early Helladic III (Reinholdt 2008) and is the only major fortified site known in the early stages of the succeeding Middle Helladic period. Crego (2010:843) has proposed that colonists from Kolonna may have been responsible for the reoccupation of Ayia Irini on Kea in Period IVa. Ships with armed men aboard are depicted on Aeginetan pottery (Siedentopf 1991:2425, pls. 35-38; Philippa-Touchais 2007:108). Some of the destructions in the Cyclades and on the mainland may have been the result of attacks and sometimes occupation by other Cycladic islanders or mainlanders, in which Kolonna may have played a prominent role, apart from raids or the movement of people from Anatolia or the Balkans. Kolonna perhaps apart, there can be no doubt continental Greece suffered a severe recession in complexity and interconnectedness by the early Middle Helladic period, nor that the Cyclades experienced a wave of destructions, depopulations in some cases, and major cultural change. The first appearance of armed hunter-warrior male images in the famed Cycladic marble figurine repertoire at the end of Early Cycladic II ca. 2300-2200 BC may signal the impending wave of destructions (Getz-Gentle 2011:33). Of course, some groups, tribes, communities, and societies are always more resourceful and resilient than others, qualities that may be displayed via local adaptation to new circumstances, or by a willingness to migrate, and/or to resort to warfare if necessary (cf. Weiberg and Finné 2013).

In addition to Anatolian impulses, eastern Adriatic Cetina culture objects and influences with their home in Dalmatia and Montenegro appear at Olympia, where Cetina-type pottery is the dominant type excavated in 1908 by Dörpfeld in the apsidal buildings there (Maran 1997:172). Cetina pottery appears elsewhere in the Peloponnese with increasing frequency towards the end of Early Helladic III, suggesting the movement of people whose typefossils appear in the Central-Western Mediterranean as well 
(Rambach 2001, 2002, 2004; Borgna and Guida 2009). Maran states the case as follows (English translation of German original):

The evidence of meaningful relationships between southern Greece and the eastern Adriatic is remarkable in and of itself, but something else is astonishing as well. Comparisons with the incised and impressed pottery of the Cetina and the EH [Early Helladic] III cultures link to a very large area...from Caput Adriae in the north to the facies of Laterza-Cellino San Marco in Apulia and to the Tarxian Cemetery culture of the Maltese islands whose pottery - as J.D. Evans and in particular M. Cavalier as well as Bernabo Brea had already realized - is in part surprisingly similar to that from Olympia. Both southern Greece and the Maltese islands share funnelrimmed bowls with one-sided, ring-shaped band handles, two-handled jugs, askoi, and footed bowls with a handle that connects the bowl to the foot... This indicates that there is a whole group of cultures with related pottery that included for a short time around $2200 \mathrm{BCE}$ almost the entire AdriaticIonian region. The sites included in this group share a number of similarities: 1 . they are usually located near the sea; 2 . the pottery appears alien within the indigenous cultural milieu, or it suddenly substitutes previous cultures; 3 . among all visible alien influences the ties to the western Balkans are by far the strongest (Maran 1997:173-174; translation including technical terms by D. Zuber, for which I am most grateful).

Early Helladic III sees the first appearance of the horse in Greece (von den Driesch and Boessneck 1990). Nomadic or seminomadic people may also arrive in Greece at this time (Rutter 1988). Barber in her seminal book on prehistoric weaving has pointed to changes in spindle whorls and the virtual absence of terracotta loomweights in Thessaly and Boeotia at this time, noting that nomads typically do not carry bulky loomweights but use pieces of local rock instead (Carington Smith 1975:218-239, 400-404; 1992:690; Barber 1991:307-308; Pavúk 2012:124). People on the move elsewhere in this epoch may be indicated by a Near Eastern text which speaks of "the seventeen [Amorite] kings who lived in tents" (Assyrian King List: Glassner 1993:147). Migrations may also result in the spread of epidemics, even when only small groups of people move (Arnott 2001:2-4, and see below).

\section{Warfare, Piracy, and the Search for Metals}

While the violent arrival of raiders and/or new settlers at some sites in mainland Greece and the Cyclades, spurred directly or indirectly by the climate event, likely played a major role, several further factors require consideration. These include the prevalence of warfare in the 3rd and 2nd millennia BC; the widespread presence of piracy in Aegean history; the impact first of the spread of furnace smelting and subsequently the appearance of tin-bronze on the number and nature of weapons; the disruption and reorganization of trading networks for metals, food, and/or prestige goods, and of accompanying relationships between societies and communities; and the coming of the age of sail. Dif- fusion and migration as explanations for dramatic change have been out of fashion for half a century. People, technologies, and ideas do move, however. For example, no one doubts that in the Middle Bronze Age beginning around the time of the failure of the Nile floods the Hyksos moved from the Levant to rule most of Egypt, before their expulsion by the resurgent Egypt of the New Kingdom.

Human propensity to war has been said to be hardwired, a necessary response to frequent food shortages in early societies (Keeley 1996). A period of good crop years produces more mouths to feed; the inevitable arrival of lean years resulting from poor weather conditions or infestations results in starvation of some of the increased population unless food or arable land is seized from neighbors. Piracy of course can occur when there are no food shortages, but may receive further impetus when shortages exist. Fernand Braudel once observed that there is usually a surplus of grain somewhere in the Mediterranean - the problem is to find it and ship it (Braudel 1972:570-576, quoted in Dickinson 2010:26), but if the severity of climate change was as great as has been suggested, grain anywhere may have been difficult to find, thus stimulating more intense and sometimes violent searches. (Even archaeologists who challenge the existence of an existential human propensity to warfare appear to accept the Old World Bronze Age era's beginning ca. $3200 \mathrm{BC}$ as violent [Ferguson 2014].)

In Early Cycladic/Early Minoan I or beginning of II, three larger daggers made of arsenical copper appear at the Cycladic colony site of Ayia Photia on Crete (Muhly 2013). Metal daggers are conspicuous in Cycladic graves in Early Cycladic II (Sherratt 2007:250). Indeed, such daggers may have been worn not merely as possessions but as symbols of status by warriors throughout much of the Mediterranean, in a period that also sees the appearance, first in western Anatolia, of the firmly hafted slotted spearhead and widespread construction of defensive circuits with bastions (Broodbank 2000:285; Branigan 2012:8). By Early Bronze II, tin-bronze, capable of producing better and more easily cast weapons, is in use at Troy. Such bronze appears at Poliochni on Lemnos, Thermi on Lesbos, and Kastri on Syros by Early Cycladic III. Weapons and other objects from Kastri are made from metal whose sources are in Anatolia (Stos-Gale et al. 1984:23, 30-36). Conflict resulting in part from the disruption of food supplies and fueled by increasing availability and/or improvement in weapons may have been more significant than food shortages in themselves in destabilizing societies.

Piracy and the seizure of captives has been endemic throughout the history of the Aegean and wider Mediterranean. At times, the threat has been sufficient to cause the abandonment of $\mathrm{Cy}$ cladic islands (Wiener 2013). Neolithic depictions carved into rocks at Strophylas on Andros already show rowing craft of some size (Televantou 2008:47-48). By at least the beginning of Early Cycladic II, longboats capable of covering 20-50 km per day and carrying substantial loads of people, animals, and food, or 
of warriors, exist (Broodbank and Strasser 1991:241; Broodbank 2000:102, 260, 287; Maran 2007; Van de Moortel 2013).

\section{Coming of the Age of the Sail}

Against this background, the appearance of sailing vessels in the Aegean would surely have transformed the prospects for trade, raid, and settlement in general, and for piratical raids in particular. Sails were apparently already in use by at least the 6th-5th millennium BC in the Persian Gulf (Carter 2006). A depiction of an Egyptian Nile boat under sail appears in the late 4th millennium BC (Broodbank 2010:255). By the end of the Predynastic period/ beginning of the Old Kingdom ca. 3200-3100 BC, large boats had become a symbol of Egyptian royal authority, as indicated by the depiction on a rock frieze of five or more sizable vessels of many oars and a ruler wearing a white crown, accompanied by standard bearers and a fan bearer (Gatto 2009: esp. 15). By the middle of the 3rd millennium, seagoing sailing vessels were traveling from Egypt to Byblos (Bietak 2010: esp. 142-143). The Annal Stone from the reign of Snofru ca. 2575-2550 BC describes 40 ships bringing wood from a foreign land and ships of 100 cubits, i.e. over $50 \mathrm{~m}$. The funerary boat from the pyramid of Khufu, his predecessor, was made with approximately 38 tons of imported cedar (Mark 2009). Broodbank (2010:255) notes that beginning in the early 25 th century BC, "monuments of the pharaohs Sahure and Unas show large, developed ships with a bipod or tripod mast... a yard above and boom below, and long oars" (see also Wachsmann 1998:13-14, Figures 2.2-8). Such ships may have brought newcomers from Anatolia to Cyprus at the beginning of the Philia phase ca. 2450-2400 BC and/or at the time of the breakdown of the Philia culture ca. 2300-2250 BC (Kouka 2009:36-40; Webb and Frankel 2013:59). By the 26th century BC during the Fourth Dynasty, substantial harbors to serve sailing vessels were created on the Red Sea (Tallet 2013). The earliest description in human history of an amphibious attack comes from the Testament of Uni around 2300 BC during the reign of the Sixth Dynasty pharaoh Pepi I. Uni describes an Egyptian assault by sea as well as by land on fortified Canaanite sites. One likely candidate is the site of Tell es-Sakan near Gaza, for most of the Old Kingdom a key port of call for Egyptian ships sailing to Byblos in the northern Levant. Byblos was the principal Egyptian trading partner in the Near East, the point of acquisition of the cedars of Lebanon, coveted by the Egyptians both for shipbuilding and embalming fluids. Tell es-Sakan with its impressive fortifications continues until the very end of the Early Bronze III period, when it is abandoned (along with the other Canaanite sites as noted above) and never reoccupied (de Miroschedji 2012:276).

Crete produces wood suitable for seagoing ships and it seems highly likely that Minoans would have soon sought to master the technology of sailing. Evidence of contact with Egypt and the Near East, beginning at Knossos (ivory tusk and stone vase fragments), Mochlos, and Tholos E at Phourni Archanes in Early Minoan IIA, and increasing greatly in the Mesara and at Archanes in Early Minoan III, surely implies voyaging in the Aegean by sail (Phillips 2008:78-82 [Knossos], 198-204 [Mochlos], 30-40 [Archanes]). The earliest secure contexts for Minoan seals and seal impressions depicting ships are probably Middle Minoan I (Broodbank 2010). Two potsherds from the Phylakopi I phase on Melos also depict ships with sails (Broodbank 2000:343). The seals, sealings, and potsherds depict an advanced sailing technology (Wedde 2000:331-333), and of course the actual technology may have been more advanced than the carver's recognition or ability to depict; moreover, there is no way of knowing how soon after their first appearance sailing vessels became a part of the seal carvers' repertoire. Seal carvers may have continued with earlier motifs because of their putative apotropaic function or in order to indicate continuity of possession or authority. Of course, voyages under sail may have been undertaken by explorers from the Eastern Mediterranean before the Minoans acquired sailing vessels.

It is worth noting another potential major factor in the collapse of civilizations ca. 2300-2000 BC: the onset of long-distance voyaging that may have brought Aegean populations into contact with pathogens to which they had no immunity. Third-millennium BC Near Eastern texts speak of the plague (McNeil 1976:78-86). Recent developments in archaeological science should one day enable us to identify the existence of such pathogens, but gauging the extent of the effect seems likely to pose an ongoing challenge. Of course, migrations by land may also bring new pathogens, even when the initial migration involves relatively small numbers. "Virgin soil" epidemics involving pathogens to which the receiving populace has no resistance are especially deadly; in such cases, the preexisting population may be devastated and largely replaced by an incoming population within two or three generations (Arnott 2001:2-3).

The arrival of the age of sail in the era of the full emergence of the Cretan palaces would have favored Crete at the expense of the Cyclades and the small-scale contemporary sites of mainland Greece, inasmuch as sailing vessels would have been available only to communities of sufficient size to shoulder the cost of obtaining suitable wood, stone anchors, materials for sails and ropes, plus the cost of training, or obtaining and retaining, highly skilled artisans and sailors (Nakou 1999:361-362; Egyptian Papyrus B.M. 10056 discussed in Glanville 1931). Minoans may have been active participants in Aegean sea raiding in Early Cycladic/ Early Helladic III, seizing captives and stores but leaving no identifying trace. A Minoan settlement is established on Kythera at least as early as Early Minoan IIB, replacing a nearby Early Helladic I-II habitation (Huxley and Coldstream 1972:69; Rutter and Zerner 1984:75). Chapin et al. (2012) have identified small deposits of gold, silver, and copper in Laconia; access to the resources of Laconia may have provided a motive for the settlement on Kythera. Early Minoan III/Middle Minoan IA sees the first appearance of Minoan pottery at Lerna, Asine, and Ayios Stephanos in the Peloponnese, and on the island of Aegina. The line dividing Crete from the Cyclades and the mainland with respect to Kastri Group and Phylakopi I material already noted continues into the 2nd millennium $\mathrm{BC}$ with respect to Aeginetan Ware, which 
appears widely on the mainland in Middle Helladic but is absent from Crete - not a single sherd has been reported from Knossos or Malia, for example, whereas Minoan pottery begins to appear in the Cyclades and, as noted, along the eastern coast of the Peloponnese. When Aegean civilization revives after the collapse, Minoan Crete is far in the lead.

\section{CONCLUSIONS}

The late 3rd millennium BC pattern is familiar: voyagers come first to trade, then to raid, and in some cases, to settle, not always peacefully. The great climate event ca. 2300-2000 BC likely provided a major impetus to the process, which also encompassed migrations, an expansion in numbers of arsenical copper daggers, the first appearance of tin-bronze weapons, and the arrival of vessels under sail. We have much yet to learn concerning the relative significance of these crucial factors and the nature of their interaction.

Two points are clear, however: (1) events in Greece, the Cyclades, and the northeast Aegean during the Early Bronze Age cannot be considered in isolation, but rather in light of events and developments of many kinds occurring in Anatolia, Cyprus, the Near East, Mesopotamia, the Levant, Canaan, Egypt, the Balkans, and the Western Mediterranean; and (2) both natural phenomena and human responses, and particularly the interaction between them, are central to our understanding of the history of humankind.

\section{ACKNOWLEDGMENTS}

I am most grateful to Phil Betancourt, Tom Brogan, Cyprian Broodbank, Jack Davis, Ourania Kouka, Joseph Maran, Robert McCabe, Dan Pullen, Jeremy Rutter, and Peter Warren for helpful suggestions, and to Jayne Warner, Erin Hayes, Jason Earle, and Rebecca Hahn for editorial assistance and many helpful suggestions with respect to clarity.

\section{REFERENCES}

Aimers, J., and D. Hodell. 2011. "Societal collapse": Drought and the Maya. Nature 479(7371):44-45.

Akkermans, P. M. M. G., and G. M. Schwartz, 2003. The Archaeology of Syria: From Complex Hunter-Gatherers to Early Urban Societies (c. 16,000-300 $B C)$. Cambridge University Press, Cambridge.

Amzallag, N., 2009. From metallurgy to Bronze Age civilizations: The synthetic theory. American Journal of Archaeology 113(4):497-519.

Angelopoulou, A., 2006. The lead seal and clay sealings. In Markiani, Amorgos: An Early Bronze Age Fortified Settlement. Overview of the 1985-1991 Investigations, edited by L. Marangou, C. Renfrew, C. Doumas, and G. Gavalas; pp. 219-223. British School at Athens Supplement 40. British School at Athens, London.

Arnott, R., 2001. Disease and Minoan Crete. Paper presented at the 9th International Congress of Cretan Studies, 1-6 October 2001, Elounda, Crete.

Arrivabeni, M., 2012. Post-Akkadian settlement distribution in the Leilan region survey. In Seven Generations since the Fall of Akkad, edited by H. Weiss; pp. 261-278. Harrassowitz, Wiesbaden.

Astour, M. C., 2002. A reconstruction of the history of Ebla (part 2). In Eblaitica: Essays on the Ebla Archives and Eblaite Language. Volume 4, edited by C. H. Gordon, and G. A. Rendsburg; pp. 57-195. Eisenbrauns, Winona Lake, IN.

Barber, E. J. W., 1991. Prehistoric Textiles: The Development of Cloth in the Neolithic and Bronze Ages. Princeton University Press, Princeton.
Bard, K. A., 2008. An Introduction to the Archaeology of Ancient Egypt. Blackwell, Malden.

Barjamovic, G., 2012. Text, trees and stratigraphy: New evidence from Kültepe for an absolute chronology of the ancient Near East. Paper presented at 58th Rencontre Assyriologique Internationale: "Private and State," 16-20 July 2012, Leiden.

Bell, B., 1971. The Dark Ages in ancient history. I. The first Dark Age in Egypt. American Journal of Archaeology 75(1):1-26.

Bertemes, F., 2011. Tavşan Adası-eine minoische Hafensiedlung nördlich von Didyma. Deutsches Archäologisches Institut Istanbul 9:9.

Betancourt, P. P., 2012. Cyprus and Crete: The transformation of the Minoan metalworking industry. In Eastern Mediterranean Metallurgy and Metalwork in the Second Millennium B.C. A Conference in Honour of James D. Muhly, Nicosia, 10th-11th October 2009, edited by V. Kassianidou, and G. Papasavvas; pp. 129-134. Oxbow, Oxford.

Bietak, M., 2010. From where came the Hyksos and where did they go? In The Second Intermediate Period (Thirteenth-Seventeenth Dynasties): Current Research, Future Prospects, edited by M. Marée; pp. 139-181. Orientalia Lovaniensia Analecta 192. Uitgeverij Peeters and Department of Oosterse Studies, Leuven.

Bietak, M., 2013. Antagonisms in historical and radiocarbon chronology. In Radiocarbon and the Chronologies of Ancient Egypt, edited by A. J. Shortland, and C. Bronk Ramsey; pp. 78-110. Oxbow, Oxford.

Bintliff, J., 2012. Environmental degradation and the decline of ancient complex societies in the Mediterranean region. In Variabilités environnementales, mutations sociales. Nature, intensités, échelles et temporalités des changements. XXXII rencontres internationales d'archéologie et d'histoire d'Antibes, edited by F. Bertoncello, and F. Braemer; pp. 213-220. Éditions APDCA, Antibes.

Booth, R. K., S. T. Jackson, S. L. Forman, J. E. Kutzbach, E. A. Bettis, III, J. Kreig, and D. K. Wright, 2005. A severe centennial-scale drought in mid-continental North America 4200 years ago and apparent global linkages. The Holocene 15(3):321-328.

Borgna, E., and P. C. Guida, 2009. Seafarers and land-travellers in the Bronze Age of the Northern Adriatic. In A Connecting Sea: Maritime Interaction in Adriatic Prehistory, edited by S. Forenbaher; pp. 89-104. British Archaeological Reports International Series 2037. Archaeopress, Oxford.

Bottema, S., and A. Sarpaki, 2003. Environmental change in Crete: A 9000-year record of Holocene vegetation history and the effect of the Santorini eruption. The Holocene 13(5):733-749.

Bourdieu, P., 1977. Outline of a Theory of Practice. Translated by R. Nice. Cambridge Studies in Social Anthropology 16. Cambridge University Press, Cambridge.

Bourdieu, P., 1990. The Logic of Practice. Translated by R. Nice. Stanford University Press, Stanford, CA.

Branigan, K., 2012. The genesis of the Early Minoan tholos tomb. In PHILISTOR: Studies in Honor of Costis Davaras, edited by E. Mantzourani, and P. P. Betancourt; pp. 8-14. INSTAP Academic Press, Philadelphia.

Braudel, F., 1972. The Mediterranean and the Mediterranean World in the Age of Philip II. Translated by S. Reynolds. Harper and Row, New York.

Brogan, T. M., 2013. "Minding the gap": Reexamining the Early Cycladic III "gap" from the perspective of Crete. A regional approach to relative chronology, networks, and complexity in the Late Prepalatial Period. American Journal of Archaeology 117(4):555-567.

Broodbank, C., 2000. An Island Archaeology of the Early Cyclades. Cambridge University Press, Cambridge.

Broodbank, C., 2010. "Ships a-sail from over the rim of the sea": Voyaging, sailing and the making of Mediterranean societies c. 3500-500 BC. In The Global Origins of Seafaring, edited by A. Anderson, J. H. Barrett, and K. Boyle; pp. 255-256. McDonald Institute Monographs, McDonald Institute for Archaeological Research, Cambridge.

Broodbank, C., 2013a. The Making of the Middle Sea: A History of the Mediterranean from the Beginning to the Emergence of the Classical World. Oxford University Press, New York.

Broodbank, C., 2013b. "Minding the gap": Thinking about change in Early Cycladic island societies from a comparative perspective. American Journal of Archaeology 117(4):535-543.

Broodbank, C., and T. F. Strasser, 1991. Migrant farmers and the Neolithic colonization of Crete. Antiquity 65(247):233-245. 
Bryce, T., 1998. The Kingdom of the Hittites. Clarendon Press, Oxford.

Butzer, K. W., 1995. Environmental change in the Near East and human impact on the land. In Civilizations of the Ancient Near East, edited by J. M. Sasson; pp. 123-151. Scribners, New York.

Butzer, K. W., 2012. Collapse, environment, and society. Proceedings of the National Academy of Science of the USA 109(10):3632-3639.

Carington Smith, J., 1975. Spinning, Weaving and Textile Manufacture in Prehistoric Greece. Doctoral dissertation, University of Tasmania, Hobart.

Carington Smith, J., 1992. Spinning and weaving equipment. In Excavations at Nichoria in Southwest Greece. Volume 2, The Bronze Age Occupation, edited by W. A. Macdonald, and N. C. Wilkie; pp. 674-711. University of Minnesota Press, Minneapolis.

Carpenter, R., 1966. Discontinuity in Greek Civilization (The J.H. Gray Lectures for 1965). Cambridge University Press, Cambridge.

Carter, R., 2006. Boat remains and maritime trade in the Persian Gulf in the sixth and fifth millennia BC. Antiquity 80(307):52-63.

Cavanagh, W., and C. Mee, 2011. Minding the gaps in Early Helladic Laconia. In Our Cups Are Full: Pottery and Society in the Aegean Bronze Age. Papers Presented to Jeremy B. Rutter on the Occasion of his 65th Birthday, edited by W. Gauss, M. Lindblom, R. A. K. Smith, and J. C. Wright; pp. 40-50. Archaeopress, Oxford.

Chapin, A. P., B. Davis, L. A. Hitchcock, and E. Banou, 2012. The Vapheio tholos tomb and the construction of a symbolic landscape in Laconia. Paper presented at the 14th Rencontre Égéenne Internationale. Physis: L'environnement natural et la relation homme-milieu dans le monde égéen protohistorique, 11-14 December, Paris.

Choleva, M., 2012. The first wheelmade pottery at Lerna: Wheel-thrown or wheel-fashioned? Hesperia 81:343-381.

Clark, J. A., 2004. Soils and land use at Pseira. In Pseira VIII: The Archaeological Survey of Pseira Island, Part 1, edited by P. P. Betancourt, and C. Davaras; pp. 27-53. INSTAP Academic Press, Philadelphia.

Cook, E. R., 2013. Megadroughts, ENSO, and the invasion of Late-Roman Europe by the Huns and Avars. In The Ancient Mediterranean Environment between Science and History, edited by W. V. Harris; pp. 89-102. Brill, Leiden.

Cooper, L., 2006. The demise and regeneration of Bronze Age urban centers in the Euphrates Valley of Syria. In After Collapse: The Regeneration of Complex Societies, edited by G. M. Schwartz, and J. J. Nichols; pp. 18-37. University of Arizona Press, Tucson.

Crego, D. M., 2010. Ayia Irini IV: A distribution center for the Middle Helladic world? In Mesohelladika: The Greek Mainland in the Middle Bronze Age, edited by A. Philippa-Touchais, G. Touchais, S. Voutsaki, and J. Wright; pp. 841-845. Bulletin de Correspondance Hellénique Supplement 52. École française d'Athènes, Athens.

Cullen, T., L. E. Talalay, D. R. Keller, L. Karimali, and W. R. Farrand, 2013. The Prehistory of the Paximadi Peninsula, Euboea. Prehistory Monographs 40. INSTAP Academic Press, Philadelphia.

Cunningham, T. F., 2012. Palaikastro in the Bronze Age: The Archaeology of a Minoan Town. Doctoral dissertation, Université catholique de Louvain.

Davaras, C., and P. P. Betancourt, 2004. The Hagia Photia Cemetery. Volume 1, The Tomb Groups and Architecture. INSTAP Academic Press, Philadelphia.

deMenocal, P. B., 2001. Cultural responses to climate change during the Late Holocene. Science 292(5517):667-673.

de Miroschedji, P., 2010. Rise and collapse in the southern Levant in the Early Bronze Age. In Le ragioni del cambiamento: nascita, declino e crollo delle società tra fine del IV e inizio del I millennio a.C., Roma, 26-29 aprile 2006, atti del convegno internazionale, edited by A. Cardarelli, A. Cazzella, M. Frangipane, and R. Peroni; pp. 101-129. Scienze dell'Antichità 15 (2009). Università degli studi "LaSapienza," Rome.

de Miroschedji, P., 2012. Egypt and southern Canaan in the third millennium BCE: Uni's Asiatic campaigns revisited. In All the Wisdom of the East: Studies in Near Eastern Archaeology and History in Honor of Eliezer D. Oren, edited by M. Gruber, S. Ahituv, G. Lehmann, and Z. Talshir; pp. 265-292. Orbus Biblicus et Orientalis 255. Academic Press, Fribourg.

Diaz, H. F., R. Trigo, M. K. Hughes, M. E. Mann, E. Xoplaki, and D. Barriopedro, 2011. Spatial and temporal characteristics of climate in medieval times revisited. Bulletin of the American Meteorological Society 92(11):1487-1500.

Dickinson, O., 1994. The Aegean Bronze Age. Cambridge University Press, Cambridge.
Dickinson, O., 2006. The Aegean from Bronze Age to Iron Age: Continuity and Change between the Twelfth and Eighth Centuries BC. Routledge, London.

Dickinson, O., 2010. The "third world" of the Aegean? Middle Helladic Greece revisited. In Mesohelladika: The Greek Mainland in the Middle Bronze Age, edited by A. Philippa-Touchais, G. Touchais, S. Voutsaki, and J. Wright; pp. 13-27. Bulletin de correspondance hellénique Supplement 52. École française d'Athènes, Athens.

Donley, D. L., 1971. Analysis of the Winter Climatic Pattern at the Time of the Mycenaean Decline. Doctoral dissertation, University of Wisconsin, Madison.

Doumas, Ch., 1992. An Early Cycladic "hooked-tang" spearhead from Naxos. In Studies in Honour of Vassos Karageorghis, edited by G. C. Ioannides, special issue. Kypriakai Spoudai 54-55(1990-1991):67-68.

Drysdale, R., G. Zanchetta, J. Hellstrom, R. Maas, A. Fallick, M. Pickett, I. Cartwright, and L. Piccini, 2006. Late Holocene drought responsible for the collapse of Old World civilizations is recorded in an Italian cave flowstone. Geology 34(2):101-104.

Eddy, J. A., 1976. The Maunder minimum. Science 192(4245):1189-1202.

Eddy, J. A., 1977. Climate and the changing sun. Climate Change 1(2):173-190.

Ellenblum, R., 2012. The Collapse of the Eastern Mediterranean: Climate Change and the Decline of the East, 950-1072. Cambridge University Press, Cambridge.

Erian, W., B. Katlan, and O. Babah, 2010. Drought vulnerability in the Arab region: Case study - Drought in Syria. Ten years of scarce water (2000-2010). Available online at http://www.unisdr.org/we/inform/publications/23905.

Falconer, S., 1994. Village economy and society in the Jordan Valley: A study of Bronze Age rural complexity. In Archaeological Views from the Countryside. Village Communities in Early Complex Societies, edited by G. Schwartz, and S. Falconer; pp. 121-142. Smithsonian Institution Press, Washington, DC.

Ferguson, R. B., 2014. The prehistory of war and peace in Europe and the Near East. In War, Peace, and Human Nature: The Convergence of Evolutionary and Cultural Views, edited by D. P. Fry; pp. 191-240. Oxford University Press, Oxford.

Finkelstein, I., and D. Langgut, 2014. Dry climate in the Middle Bronze I and its impact on settlement patterns in the Levant and beyond: New pollen evidence. Journal of Near Eastern Studies 73(2):219-234.

Finné, M., K. Holmgren, H. S. Sundqvist, E. Weiberg, and M. Lindblom, 2011. Climate in the Eastern Mediterranean, and adjacent regions, during the past 6000 years - A review. Journal of Archaeological Science 38(12):3153-3173.

Fisher, D., E. Osterberg, A. Dyke, D. Dahl-Jensen, M. Demuth, C. Zdanowicz, J. Bourgeois, R. M. Koerner, P. Mayewski, C. Wake, K. Kreutz, E. Steig, J. Zheng, K. Yalcin, K. Goto-Azuma, B. Luckman, and S. Rupper, 2008. The Mt Logan Holocene-Late Wisconsinan isotope record: Tropical Pacific-Yukon connections. The Holocene 18(5):667-677.

Forsén, J., 1992. The Twilight of the Early Helladics: A Study of the Disturbances in East-Central and Southern Greece towards the End of the Early Bronze Age. Paul Åström, Jonsered, Sweden.

Frankel, D., and J. M. Webb, 2012. Pottery production and distribution in prehistoric Bronze Age Cyprus. An application of pXRF analysis. Journal of Archaeological Science 39(5):1380-1387.

Freemon, F. R., 2005. Bubonic plague in the Book of Samuel. Journal of the Royal Society of Medicine 98(9):436.

French, C. A. I., and T. M. Whitelaw, 1999. Soil erosion, agricultural terracing and site formation processes at Markiani, Amorgos, Greece: The micromorphological perspective. Geoarchaeology 14(2):151-189.

Gatto, M. C., 2009. The Aswan area at the dawn of Egyptian history. Egyptian Archaeology 35:12-15.

Gejvall, N.-G., 1969. Lerna: A Preclassical Site in the Argolid. Results of the Excavations Conducted by the American School of Classical Studies at Athens. Volume 1, The Fauna. American School of Classical Studies at Athens, Princeton.

Georgiadis, M., 2012. Kos in the Neolithic and Early Bronze Age. The Halasarna Finds and the Aegean Settlement Pattern. Prehistory Monographs 38. INSTAP Academic Press, Philadelphia.

Getz-Gentle, P., 2011. Overview/panorama. In Zervos et l'art des Cyclades, edited by A. Caubet; pp. 17-39. Musée Zervos, Vézelay.

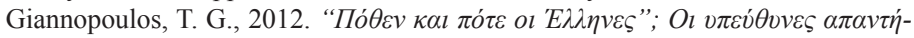

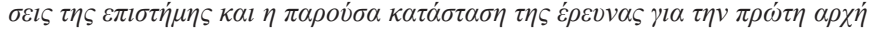

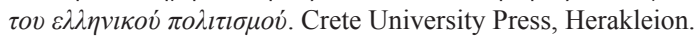


Giddens, A., 1984. The Constitution of Society: Outline of the Theory of Structuration. University of California Press, Berkeley.

Giraudi, C., M. Magny, G. Zanchetta, and R. N. Drysdale, 2011. The Holocene climatic evolution of Mediterranean Italy: A review of the continental geological data. The Holocene 21(1):105-115.

Glanville, S. R. K., 1931. Records of a royal dockyard of the time of Tuthmosis III: Papyrus British Museum 10056. Zeitschrift für ägyptische Sprache und Altertumskunde 66:105-121.

Glassner, J.-J., 1993. Chroniques mésopotamiennes. La Roue à Livres 19. Les Belles Lettres, Paris.

Goedicke, H., 1984. The Canaanite illness. Studien zur Altägyptischen Kultur 11:91-105.

Gophna, R., and Y. Portugali, 1988. Settlement and demographic processes in Israel's coastal plain from the Chalcolithic to the Middle Bronze Age. Bulletin of the American School of Oriental Research 269:3-36.

Grove, J. M., 1988. The Little Ice Age. Methuen, London.

Harbeck, M., L. Seifert, S. Hänsch, D. M. Wagner, D. Birdsell, K. L. Parise, I. Wiechmann, G. Grupe, A. Thomas, P. Keim, L. Zöller, B. Bramanti, J. M. Riehm, and H. C. Scholz, 2013. Yersinia pestis DNA from skeletal remains from the 6th century AD reveals insights into Justinianic plague. PLOS Pathogens 9(5):e1003349, doi: 10.1371/journal.ppat.1003349.

Hauptmann, H., 1976. Die Entwicklung der Frühbronzezeitlichen Siedlung auf dem Norşuntepe in Ostanatolien. Archäologisches Korrespondenzblatt 6:920.

Herr, S., and J. J. Clark, 1997. Patterns in the pathways: Early historic migrations in the Rio Grande pueblos. Kiva 62(4):365-389.

Hood, M. S. F., 1971. An Early Helladic import at Knossos and Anatolian connections. In Mélanges de préhistoire d'archéocivilization et d'ethnologie offerts à André Varagnac, edited by G. Marcel; pp. 427-436. Sevpen, Paris.

Hope Simpson, R., and R. Janko, 2011. Ayios Stephanos in southern Laconia and the locations of ancient Helos. Studi Micenei ed Egeo-Anatolici 53:97-130.

Hsiang, S. M., M. Burke, and E. Miguel, 2013. Quantifying the influence of climate on human conflict. Science 341(6151):1212.

Huxley, G. L., and J. N. Coldstream, 1972. Trial excavations near Kastri. In Kythera: Excavations and Studies Conducted by the University of Pennsylvania Museum and the British School at Athens, edited by J. N. Coldstream, and G. L. Huxley; pp. 67-76. Faber and Faber Limited, London.

Keeley, L. H., 1996. War Before Civilization: The Myth of the Peaceful Savage. Oxford University Press, Oxford.

Kennett, D. J., S. F. M. Breitenbach, V. V. Aquino, Y. Asmerom, J. Awe, J. U. L. Baldini, P. Bartlein, B. J. Culleton, C. Ebert, C. Jazwa, M. J. Macri, N. Marwan, V. Polyak, K. M. Prufer, H. E. Ridley, H. Sodemann, B. Winterhalder, and G. H. Haug, 2012. Development and disintegration of Maya political systems in response to climate change. Science 338(6108):788-791.

Kilian, K., 1986. The circular building at Tiryns. In Early Helladic Architecture and Urbanization. Proceedings of a Seminar Held at the Swedish Institute at Athens, June 8, 1985, edited by R. Hägg, and D. Konsola; pp. 65-71. Studies in Mediterranean Archaeology 76. Paul Åström, Göteborg.

Koliński, R., 2007. The upper Khabur region in the second part of the third millennium BC. Altorientalische Forschungen 34(2):342-369.

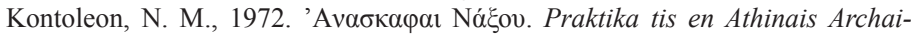
ologikis Etaireias 125:143-155.

Kouka, O., 2002. Siedlungsorganisation in der Nord- und Ostägäis während der Frühbronzezeit (3. Jt. v.Chr.). Internationale Archäologie 58. Verlag Marie Leidorf GmbH, Rahden/Westfalen.

Kouka, O., 2009. Cross-cultural links and elite-identities: The eastern Aegean/ western Anatolia and Cyprus from the early third millennium through the early second millennium BC. In Cyprus and the East Aegean: Intercultural Contacts from 3000 to 500 BC. An International Archaeological Symposium Held at Pythagoreion, Samos, October 17th-18th 2008, edited by V. Karageorghis, and O. Kouka; pp. 31-47. A.G. Leventis Foundation, Nicosia.

Kouka, O., 2013. "Minding the gap": Against the gaps. The Early Bronze Age and the transition to the Middle Bronze Age in the northern and eastern Aegean/ western Anatolia. American Journal of Archaeology 117(4):569-580.

Langgut, D., F. H. Neumann, M. Stein, A. Wagner, E. J. Kagan, E. Boaretto, and I. Finkelstein, 2014. Dead Sea pollen record and history of human activity in the Judean Highlands (Israel) from the Intermediate Bronze into the Iron Ages ( 2500-500 BCE). Palynology 38(2):280-302.
Larson, D. O., H. Neff, and D. A. Graybill, 1996. Risk, climatic variability, and the study of Southwestern prehistory: An evolutionary perspective. American Antiquity 61(2):217-241.

Magny, M., 1993. Solar influences on Holocene climatic changes illustrated by correlations between past lake-level fluctuations and the atmospheric ${ }^{14} \mathrm{C}$ record. Quaternary Research 40(1):1-9.

Magny, M., B. Vannière, G. Zanchetta, E. Fouache, G. Touchais, L. Petrika, C. Coussot, A.-V. Walter-Simonnet, and F. Arnaud, 2009. Possible complexity of the climatic event around 4300-3800 cal. BP in the Central and Western Mediterranean. The Holocene 19(6):823-833.

Manning, S., 2013. Cyprus at 2200 BC: Rethinking the chronology of the Cypriot Early Bronze Age. In J. R. B. Stewart: An Archaeological Legacy, edited by A. B. Knapp, J. M. Webb, and A. McCarthy; pp. 1-21. Studies in Mediterranean Archaeology 139. Åströms Förlag, Uppsala.

Maran, J., 1997. Neue Ansätze für die Beurteilung der Balkanisch-Ägäischen Beziehungen im 3. Jahrtausend v. Chr. In The Thracian World at the Crossroads of Civilizations I: Proceedings of the Seventh International Congress of Thracology, Constanţa-Mangalia-Tulcea, 20-26 May 1996, edited by P. Roman; pp. 171-192. Institutul Român de Tracologie, Bucharest.

Maran, J., 2007. Seaborne contacts between the Aegean, the Balkans and the Central Mediterranean in the 3rd millennium BC: The unfolding of the Mediterranean world. In Between the Aegean and Baltic Seas: Prehistory across Borders. Proceedings of the International Conference Bronze and Early Iron Age Interconnections and Contemporary Developments between the Aegean and the Regions of the Balkan Peninsula, Central and Northern Europe, University of Zagreb, 11-14 April 2005, edited by I. Galanaki, H. Tomas, Y. Galanakis, and R. Laffineur; pp. 3-21. Aegaeum 27. Université de Liège, Histoire de l'art et archeology de la Grèce antique, Liège.

Mariolopoulos, E. G., 1938. The Climate of Greece. A. A. Papaspyros, Athens.

Mark, S., 2009. The construction of the Khufu I vessel (c.2566 BC): A re-evaluation. International Journal of Nautical Archaeology 38(1):133-152.

Matthews, R., 2002. Zebu: Harbingers of doom in Bronze Age western Asia? Antiquity 76(292):438-446.

Mayewski, P. A., E. E. Rohling, J. C. Stager, W. Karlén, K. A. Maasch, L. D. Meeker, E. A. Meyerson, F. Gasse, S. van Kreveld, K. Holmgren, J. LeeThorp, G. Rosqvist, F. Rack, M. Staubwasser, R. R. Schneider, and E. J. Steig, 2004. Holocene climate variability. Quaternary Research 62(3):243-255.

Mazar, A., 1990. Archaeology of the Land of the Bible. Doubleday, New York.

McAnany, P. A., and N. Yoffee, 2010. Questioning Collapse: Human Resilience, Ecological Vulnerability, and the Aftermath of Empire. Cambridge University Press, Cambridge.

McCormick, M., 2013. What climate science, Ausonius, Nile floods, rye, and thatch tell us about the environmental history of the Roman Empire. In The Ancient Mediterranean Environment between Science and History, edited by W. V. Harris; pp. 61-88. Brill, Leiden.

McCormick, M., U. Büntgen, M. A. Cane, E. R. Cook, K. Harper, P. Huybers, T. Litt, S. W. Manning, P. A. Mayewski, A. F. M. More, K. Nicolussi, W. Tegel, 2012. Climate change during and after the Roman Empire: Reconstructing the past from scientific and historical evidence. Journal of Interdisciplinary History 43(2):169-220.

McNeil, W., 1976. Plagues and Peoples. Anchor Books, New York.

Medina-Elizalde, M., and E. J. Rohling, 2012. Collapse of Classic Maya Civilization related to modest reduction in precipitation. Science 335(6071):956-959.

Middleton, G. D., 2012. Nothing lasts forever: Environmental discourses on the collapse of past societies. Journal of Archaeological Science 20(3):257-307.

Moody, J., 2009. Environmental change and Minoan sacred landscapes. In $\mathrm{Ar}$ chaeologies of Cult: Essays on Ritual and Cult in Crete in Honor of Geraldine C. Gesell, edited by A. L. D'Agata, and A. Van de Moortel; pp. 241-249. Hesperia Supplement 42. American School of Classical Studies at Athens, Princeton.

Muhly, J. D., 1993. Early Bronze Age tin and the Taurus. American Journal of Archaeology 97(2):239-253.

Muhly, J. D., 2013. Eastern Mediterranean metallurgy in the Final Neolithic/ Late Chalcolithic: Crete enters the international world. Paper presented at the 114th Annual Meeting of the Archaeological Institute of America, 3-6 January 2013, Seattle.

Nakou, G., 1999. The End of the Early Bronze Age in the Aegean: Material Culture and History. Doctoral dissertation, University of Oxford. 
Nakou, G., 2007. Absent presences: Metal vessels in the Aegean at the end of the third millennium. In Metallurgy in the Early Bronze Age Aegean, edited by P. M. Day, and R. C. P. Doonan; pp. 224-244. Sheffield Studies in Aegean Archaeology 7. Oxbow, Oxford.

Nodarou, E., 2011. Pottery Production, Distribution and Consumption in Early Minoan West Crete: An Analytical Perspective. BAR International Series 2210. Archaeopress, Oxford.

Nowicki, K., 2013. Settlement patterns and social organization in Crete during the Final Neolithic and in the beginning of the Bronze Age, ca. 4000-3000 BC. Paper presented at Communities in Transition: The Circum-Aegean Later Neolthic Stages (ca. 5000/4800-3200/3000 BC), 7-9 June 2013, Athens.

O'Brien, S., 2013. Parables of decline: Popular fears and the use of crises in Aegean archaeological interpretation. In Tough Times: The Archaeology of Crisis and Recovery. Proceedings of the Graduate Archaeology at Oxford Conferences in 2010 and 2011, edited by E. M. van der Wilt, and J. Martínez Jiménez; pp. 13-22. BAR International Series 2478. Archaeopress, Oxford.

Oren, E. D., 2003. Interconnections between the southern Levant and the Aegean at the end of the Early Bronze Age. In Eretz-Israel: Archaeological, Historical and Geographical Studies. Volume 27: Hayim and Miriam Tadmor, edited by I. Eph`al, A. Ben-Tor, and P. Machinist; pp. 10-17. Israel Exploration Society, Jerusalem. In Hebrew.

Paine, R. R., 2000. If a population crashes in prehistory, and there is no paleodemographer there to hear it, does it make a sound? American Journal of Physical Anthropology 112(2):181-190.

Papazoglou-Manioudaki, L., 2010. The Middle Helladic and Late Helladic I periods at Aigion in Achaia. In Mesohelladika: The Greek Mainland in the Middle Bronze Age, edited by A. Philippa-Touchais, G. Touchais, S. Voutsaki, and J. Wright; pp. 129-141. Bulletin de correspondance hellénique Supplement 52. École française d'Athènes, Athens.

Parker, G., 2013. Global Crisis: War, Climate Change and Catastrophe in the Seventeenth Century. Yale University Press, New Haven.

Pavúk, P., 2012. Of spools and discoid loom-weights: Aegean-type weaving at Troy revisited. In KOSMOS: Jewellery, Adornment and Textiles in the Aegean Bronze Age. Proceedings of the 13th International Aegean Conference, University of Copenhagen, Danish National Research Foundation's Centre for Textile Research, 21-26 April 2010, edited by M.-L. Nosch, and R. Laffineur; pp. 121-130. Aegaeum 33. Peeters, Leuven.

Pavúk, P., M. Pieniazek, and S. Riehl, forthcoming. Troy and the Troad in the 2nd millennium: Changing patterns of landscape use. In PHYSIS: L'environnement naturel et la relation homme-milieu dans le monde égéen protohistorique. 14ème Rencontre Égéenne Internationale, 11-14 décembre 2012, Paris, edited by G. Touchais, R. Laffineur, S. Andreou, F. Rougemont, H. Procopiou, and E. Fouache. Aegaeum.

Pederson, N., A. E. Hessl, N. Baatarbileg, K. J. Anchukaitis, and N. Di Cosmo, 2014. Pluvials, droughts, the Mongol Empire, and modern Mongolia. Proceedings of the National Academy of Sciences of the USA 111(12):4375-4379.

Peltenburg, E., 2007. Diverse settlement pattern changes in the Middle Euphrates Valley in the later third millennium B.C.: The contribution of Jerablus Tahtani. In Sociétés humaines et changement climatique à la fin du troisième millénaire: une crise a-t-elle eu lieu en haute Mésopotamie? Actes du Colloque de Lyon, 5-8 décembre 2005, edited by C. Kuzucuoğlu, and C. Marro; pp. 247-266. Varia Anatolica 19. Institut français d'études anatoliennes Georges-Dumézil, Istanbul.

Perrow, C., 1999. Normal Accidents: Living with High-Risk Technologies. Princeton University Press, Princeton.

Pfälzner, P., 2012. The question of desurbanisation versus reurbanisation of the Syrian Jazirah in the late third and early second millennium BC. In Looking North: The Socioeconomic Dynamics of the Northern Mesopotamian and Anatolian Regions during the Late Third and Early Second Millennium BC, edited by N. Laneri, P. Pfälzner, and S. Valentini; pp. 51-80. Harrassowitz, Wiesbaden.

Philippa-Touchais, A., 2007. Aeginetan matt-painted pottery at Middle Helladic Aspis, Argos. In Middle Helladic Pottery and Synchronisms. Proceedings of the International Workshop Held at Salzburg, 31 October-2 November 2004, edited by F. Felten, W. Gauss, and R. Smetana; pp. 97-113. Ägina-Kolonna Forschungen und Ergebnisse I. Österreichischen Akademie der Wissenschaften, Vienna.

Philippa-Touchais, A., 2011. "Cycles of collapse in Greek prehistory": Reassess- ing social change at the beginning of the Middle Helladic and the Early Iron Age. In The "Dark Ages" Revisited. Acts of an International Symposium in Memory of William D.E. Coulson, University of Thessaly, Volos, 14-17 June 2007, edited by A. Mazarakis Ainian; pp. 31-44. University of Thessaly Press, Volos.

Phillips, J., 2008. Aegyptiaca on the Island of Crete in Their Chronological Context: A Critical Review. Volume 2. Österreichische Akademie der Wissenschaften, Vienna.

Porter, A., 2007. You say potato, I say.... In Sociétés humaines et changement climatique à la fin du troisième millénaire: une crise a-t-elle eu lieu en Haute Mésopotamie? Actes du Colloque de Lyon, 5-8 décembre 2005, edited by C. Kuzucuoğlu, and C. Marro; pp. 69-115. Varia Anatolica 19. Institut français d'études anatoliennes Georges-Dumézil, Istanbul.

Porter, J. H., M. L. Parry, and T. R. Carter, 1991. The potential effects of climatic change on agricultural insect pests. Agricultural and Forest Meteorology 57(1-3):221-240.

Rackham, O., and J. Moody, 1996. The Making of the Cretan Landscape. Manchester University Press, Manchester.

Rahmstorf, L., 2003. The identification of Early Helladic weights and their wider implications. In METRON: Measuring the Aegean Bronze Age. Proceedings of the 9th International Aegean Conference, New Haven, Yale University, 18-21 April 2002, edited by K. P. Foster, and R. Laffineur; pp. 293-299. Aegaeum 24. Université de Liège, Histoire de l'art et archeology de la Grèce antique, Liège.

Rahmstorf, L., 2006a. In search of the earliest balance weights, scales and weighing systems from the East Mediterranean, the Near and Middle East. In Weights in Context: Bronze Age Weighing Systems of Eastern Mediterranean. Chronology, Typology, Material, and Archaeological Contexts. Proceedings of the International Colloquium, Rome, 22nd November-24th November 2004, edited by M. E. Alberti, E. Ascalone, and L. Peyronel; pp. 9-45. Studi e Materiali 13. Istituto Italiano di Numismatica, Rome.

Rahmstorf, L., 2006b. Zur Ausbreitung vorderasiatischer Innovationen in die frühbronzezeitliche Ägäis. Prähistorische Zeitschrift 81(1):49-96.

Rahmstorf, L., 2011. Re-integrating "diffusion": The spread of innovations among the Neolithic and Bronze Age societies of Europe and the Near East. In Interweaving Worlds: Systemic Interactions in Eurasia, 7th to 1st Millennia BC, edited by T. C. Wilkinson, S. Sherratt, and J. Bennet; pp. 100-119. Oxbow, Oxford.

Rambach, J., 2001. Bermerkungen zur Zeitstellung der Apsidenhäuser in der Altis von Olympia. In Lux Orientis. Archäologie zwischen Asien und Europa, edited by R. M. Boehmer, and J. Maranpp. 327-332. Internationale Archäologie, Studia honoraria 12. Marie Leidorf, Rahden/Westfalen.

Rambach, J., 2002. Olympia. 2500 Jahre Vorgeschichte vor der Gründung des eisenzeitlichen griechischen Heiligtums. In Olympia 1875-2000. 125 Jahre Deutsche Ausgrabungen. Internationales Symposion, Berlin 9.-11. November 2000, edited by H. Kyrieleis; pp. 191-200. Philipp von Zabern, Mainz am Rhein.

Rambach, J., 2004. Olympia im ausgehenden 3. Jahrtausend v. Chr.: Bindeglied zwischen zentralem und östlichem Mittelmeerraum. In Die Ägäische Frühzeit. 2. Serie: Forschungsbericht 1975-2002. 2. Band: Die Frühbronzezeit in Griechenland mit Ausnahme von Kreta, edited by E. Alram-Stern; pp. 11991242. Veröffentlichungen der Mykenischen Kommission 21. Österreichische Akademie der Wissenschaften, Vienna.

Rambeau, C., and S. Black, 2011. Paleoenvironments of the southern Levant $5,000 \mathrm{BP}$ to present: Linking the geological and archaeological records. In Water, Life and Civilisation: Climate, Environment and Society in the Jordan Valley, edited by S. Mithen, and E. Black; pp. 94-104. International Hydrology Series. Cambridge University Press, Cambridge.

Redford, D. B., 1992. Egypt, Canaan and Israel in Ancient Times. Princeton University Press, Princeton.

Regev, J., P. de Miroschedji, and E. Boaretto, 2012a. Early Bronze Age chronology: Radiocarbon dates and chronological models from Tel Yarmuth (Israel). Radiocarbon 54(3-4):505-524.

Regev, J., P. de Miroschedji, R. Greenberg, E. Braun, Z. Greenhut, and E. Boaretto, 2012b. Chronology of the Early Bronze Age in the Southern Levant: New analysis for a high chronology. Radiocarbon 54(3-4):525-566.

Reinholdt, C., 2008. Der frühbronzezeitliche Schmuckhortfund von Kap Kolonna: Ägina und die Ägäis im Goldzeitalter des 3. Jahrtausends v. Chr. Österre- 
ichische Akademie der Wissenschaften, Vienna.

Renfrew, C., 1975. Trade as action at a distance: Questions of integration and communication. In Ancient Civilization and Trade, edited by J. A. Sabloff, and C. C. Lamberg-Karlovsky; pp. 3-59. University of New Mexico Press, Albuquerque.

Renfrew, C., 1977. Alternative models for exchange and spatial distribution. In Exchange Systems in Prehistory, edited by T. K. Earle, and J. E. Ericson; pp. 71-90. Academic Press, New York.

Renfrew, C., O. Philaniotou, N. Brodie, and G. Gavalas, 2009. The Early Cycladic settlement at Dhaskalio, Keros: Preliminary report of the 2008 excavation season. Annual of the British School at Athens 104:27-47.

Renfrew, C., M. Boyd, and C. Bronk Ramsey, 2012. The oldest maritime sanctuary? Dating the sanctuary at Keros and the Cycladic Early Bronze Age. Antiquity 86(331):144-160.

Riehl, S., 2008. Changing growing conditions for crops during the Near Eastern Bronze Age (3000-1200 BC): The stable carbon isotope evidence. Journal of Archaeological Science 35(4):1011-1022.

Riehl, S., 2009. Archaeobotanical evidence for the interrelationship of agricultural decision-making and climate change in the ancient Near East. Quaternary International 197(1-2):93-114.

Riehl, S., K. E. Pustovoytov, H. Weippert, S. Klett, and F. Hole, 2014. Drought stress variability in ancient Near Eastern agricultural systems evidenced by $\delta^{13} \mathrm{C}$ in barley grain. Proceedings of the National Academy of Sciences of the USA 111(34): 12,348-12,353.

Ritner, R. K., 2000. Innovations and adaptations in ancient Egyptian medicine. Journal of Near Eastern Studies 59(2):107-117.

Roberts, N., W. J. Eastwood, C. Kuzucuoğlu, G. Fiorentino, and V. Caracuta, 2011. Climatic, vegetation and cultural change in the Eastern Mediterranean during the mid-Holocene environmental transition. The Holocene 21(1):147-162.

Rosen, A., 2007. Civilizing Climate: Social Responses to Climate Change in the Ancient Near East. AltaMira, Lanham.

Ruddiman, W. F., 2005. How did humans first alter global climate? Scientific American 292:46-53.

Rutter, J. B., 1988. Early Helladic III vasepainting, ceramic regionalism and the influence of basketry. In Problems in Greek Prehistory. Papers Presented at the Centenary Conference of the British School of Archaeology at Athens, Manchester April 1986, edited by E. B. French, and K. A. Wardle; pp. 73-89. Bristol Classical Press, Bristol.

Rutter, J. B., 2001. The Prepalatial Bronze Age of the southern and central Greek mainland. In Aegean Prehistory: A Review, edited by T. Cullen; pp. 95-147. American Journal of Archaeology Supplement 1. Archaeological Institute of America, Boston. Originally published in American Journal of Archaeology 97(4):745-797 (1993).

Rutter, J. B., 2008. The Anatolian roots of Early Helladic III drinking behavior. In Proceedings of the International Symposium The Aegean in the Neolithic, Chalcolithic and the Early Bronze Age, October 13th-19th 1997, Urla-İzmir (Turkey), edited by H. Erkanal, H. Hauptmann, V. Şahoğlu, and R. Tuncel; pp. 461-481. Ankara University, Ankara.

Rutter, J. B., and C. W. Zerner, 1984. Early Hellado-Minoan contacts. In The Minoan Thalassocracy: Myth and Reality. Proceedings of the Third International Symposium at the Swedish Institute in Athens, 31 May-5 June, 1982, edited by R. Hägg, and N. Marinatos; pp. 75-83. Skrifter utgivna av Svenska Institutet $i$ Athen $4^{\circ}$, 32. Paul Åström, Stockholm.

Şahoğlu, V., 2008. Liman Tepe and Bakla Tepe: New evidence for the relations between the Izmir region, the Cyclades and the Greek mainland during the late fourth and third millennia BC. In Proceedings of the International Symposium The Aegean in the Neolithic, Chalcolithic and the Early Bronze Age, October 13th-19th 1997, Urla-İzmir (Turkey), edited by H. Erkanal, H. Hauptmann, V. Şahoğlu, and R. Tuncel; pp. 483-501. Ankara University, Ankara.

Salzer, M. W., A. G. Bunn, N. E. Graham, and M. K. Hughes, 2014. Five millennia of paleotemperature from tree-rings in the Great Basin, USA. Climate Dynamics 42(5-6):1517-1526.

Scheffer, M., S. R. Carpenter, T. M. Lenton, J. Bascompte, W. Brock, V. Dakos, J. van de Koppel, I. A. van de Leemput, S. A. Levin, E. H. van Nes, M. Pascual, and J. Vandermeer, 2012. Anticipating critical transitions. Science 338(6105):344-348

Schwartz, G. M., 2007. Taking the long view on collapse: A Syrian perspective. In
Sociétés humaines et changement climatique à la fin du troisième millénaire: une crise a-t-elle eu lieu en Haute Mésopotamie? Actes du Colloque de Lyon, 5-8 décembre 2005, edited by C. Kuzucuoğlu, and C. Marro; pp. 45-68. Varia Anatolica 19. Institut français d'études anatoliennes Georges-Dumézil, Istanbul.

Schwartz, G. M., H. H. Curvers, S. S. Dunham, and J. A. Weber, 2012. From urban origins to imperial integration in Western Syria: Umm el-Marra 2006, 2008. American Journal of Archaeology 116(1):157-193.

Shelach, G., 2012. The rise, decline and transformation of early regional states in China. Paper presented at Analyzing Collapse: Destruction, Abandonment and Memory, 10-16 December 2012, Jerusalem.

Sherratt, S., 2007. The archaeology of metal use in the Early Bronze Age Aegean: A review. In Metallurgy in the Early Bronze Age Aegean, edited by P. M. Day, and R. C. P. Doonan; pp. 245-263. Sheffield Studies in Aegean Archaeology 7. Oxbow, Oxford.

Siedentopf, H. B., 1991. Alt-Ägina. Volume 4.2, Mattbemalte Keramik der Mittleren Bronzezeit. Philipp von Zabern, Mainz.

Snodgrass, A. M., 1971. The Dark Age of Greece: An Archaeological Survey of the Eleventh to the Eighth Centuries BC. Edinburgh University Press, Edinburgh.

Snodgrass, A. M., 2006. The rejection of Mycenaean culture and the Oriental connection. In Archaeology and the Emergence of Greece. Collected Papers 1965-2002; pp. 158-172. Cornell University Press, Ithaca.

Sohl, M., 2010. Tackling the drought in Syria. Nature Middle East, 27 September. doi:10.1038/nmiddleeast.2010.206.

Sotirakopoulou, P., 1993. The chronology of the Kastri Group reconsidered. Annual of the British School at Athens 88:5-20.

Spitaels, P., 1984. The Early Helladic period in mine no. 3 (Theatre Sector). In Thorikos 1972/76. Volume 8, Rapport préliminaire sur les $9^{e}, 10^{e}, 11^{e}$ et $12^{e}$ campagnes de fouilles, edited by H. F. Mussche, J. Bingen, J. Servais, and P. Spitaels; pp. 151-174. Comité des fouilles belges en Grèce, Ghent.

Stanley, J.-D., M. D. Krom, R. A. Cliff, and J. C. Woodward, 2003. Short contribution: Nile flow failure at the end of the Old Kingdom, Egypt: Strontium isotopic and petrologic evidence. Geoarchaeology 18(3):395-402.

Staubwasser, M., and H. Weiss, 2006. Holocene climate and cultural evolution in late prehistoric-early historic West Asia. Quaternary Research 66(3):372-387.

Stos-Gale, Z. A., N. H. Gale, and G. R. Gilmore, 1984. Early Bronze Age Trojan metal sources and Anatolians in the Cyclades. Oxford Journal of Archaeology $3(3): 23-43$.

Tallet, P., 2013. The Wadi el-Jarf site: A harbor of Khufu on the Red Sea. Journal of Ancient Egyptian Interconnections 5(1):76-84.

Televantou, C. A., 2008. Strofilas: A Neolithic settlement on Andros. In Horizon: A Colloquium on the Prehistory of the Cyclades, edited by N. Brodie, J. Doole, G. Gavalas, and C. Renfrew; pp. 43-53. McDonald Institute Monographs. McDonald Institute for Archaeological Research, Cambridge.

Thompson, L. G., E. Mosley-Thompson, M. E. Davis, K. A. Henderson, H. H. Brecher, V. S Zagorodnov, T. A. Mashiotta, P.-N. Lin, V. N. Mikhalenko, D. R. Hardy, and J. Beer, 2002. Kilimanjaro ice core records: Evidence of Holocene climate change in tropical Africa. Science 298(5593):589-593.

Tomkins, P., 2012. Behind the horizon: Reconsidering the genesis and function of the 'First Palace' at Knossos (Final Neolithic IV-Middle Minoan IB). In Back to the Beginning: Reassessing Social and Political Complexity on Crete during the Early and Middle Bronze Age, edited by I. Schoep, P. Tomkins, and J. Driessen; pp. 32-80. Oxbow, Oxford.

Touzeau, A., J. Blichert-Toft, R. Amiot, F. Fourel, F. Martineau, J. Cockitt, K. Hall, J.-P. Flandrois, and C. Lécuyer, 2013. Egyptian mummies record increasing aridity in the Nile Valley from 5500 to $1500 \mathrm{yr}$ before present. Earth and Planetary Science Letters 375:92-100.

Triantaphyllou, M. V., P. Ziveri, A. Gogou, G. Marino, V. Lykousis, I. Bouloubassi, K.-C. Emeis, K. Kouli, M. Dimiza, A. Roselle-Melé, M. Papanikolaou, G. Katsouras, and N. Nunez, 2009. Late Glacial-Holocene climate variability at the south-eastern margin of the Aegean Sea. Marine Geology 266(1-4):182197.

Ur, J., 2010a. Cycles of civilization in northern Mesopotamia, 4400-2000 BC. Journal of Archaeological Research 18(4):387-431.

Ur, J., 2010b. Urbanism and Cultural Landscapes in Northeastern Syria: The Tell Hamoukar Survey 1999-2001. Oriental Institute Publications 137. Oriental Institute of the University of Chicago, Chicago. 
Van Andel, T. H., C. N. Runnels, and K. O. Pope, 1986. Five thousands[sic] years of land use and abuse in the southern Argolid, Greece. Hesperia 55(1):103128.

Van de Moortel, A., 2013. The emergence of a warlike elite at Mitrou, East Lokris, in the Prepalatial Bronze Age. Paper presented at the American School of Classical Studies at Athens, 10 October 2013, Athens.

Vitale, S., 2013. The Asklupis reconsidered: A preliminary report on the chronology and burial practices of an Early Bronze Age 2 cemetery on Kos. Aegean Archaeology 10:47-63.

von den Driesch, A., and J. Boessneck, 1990. Die Tierreste von der mykenischen Burg Tiryns bei Nauplion/Peloponneses. In Tiryns: Forschungen und Berichte XI, edited by H.-J. Weisshaar, I. Weber-Hiden, A. von den Driesch, J. Boessneck, A. Rieger, and W. Böser; pp. 87-164. Philipp von Zabern, Mainz am Rhein.

Wachsmann, S., 1998. Seagoing Ships and Seamanship in the Bronze Age Levant. Texas A\&M University Press, College Station.

Walker, M. J. C., M. Berkelhammer, S. Björck, L. C. Cwynar, D. A. Fisher, A. J. Long, J. J. Lowe, R. M. Newnham, S. O. Rasmussen, and H. Weiss, 2012. Formal subdivision of the Holocene Series/Epoch: A discussion paper by a Working Group of INTIMATE (Integration of the ice-core, marine and terrestrial records) and the Subcommission on Quaternary Stratigraphy (International Commission on Stratigraphy). Journal of Quaternary Science 27(7):649-659.

Wang, Y., H. Cheng, R. L. Edwards, Y. He, X. Kong, Z. An, J. Wu, M. J. Kelly, C. A. Dykoski, and X. Li, 2005. The Holocene Asian monsoon: Links to solar changes and North Atlantic climate. Science 308(5723):854-857.

Watrous, L. V., 2004. State formation (Middle Minoan IA). In The Plain of Phaistos: Cycles of Social Complexity in the Mesara Region of Crete, edited by L. V. Watrous, D. Hadzi-Vallianou, and H. Blitzer; pp. 253-276. Monumenta Archaeologica 23. Cotsen Institute of Archaeology, University of California, Los Angeles.

Watrous, L. V., and D. Hadzi-Vallianou, 2004. Conclusions. In The Plain of Phaistos: Cycles of Social Complexity in the Mesara Region of Crete, edited by L. V. Watrous, D. Hadzi-Vallianou, and H. Blitzer; pp. 443-449. Monumenta Archaeologica 23. Cotsen Institute of Archaeology, University of California, Los Angeles.

Webb, J. M., and D. Frankel, 1999. Characterizing the Philia facies. Material culture, chronology and the origin of the Bronze Age in Cyprus. American Journal of Archaeology 103(1):3-43.

Webb, J. M., and D. Frankel, 2013. Cultural regionalism and divergent social trajectories in Early Bronze Age Cyprus. American Journal of Archaeology 117(1):59-81.

Wedde, M., 2000. Towards a Hermeneutics of Aegean Bronze Age Ship Imagery. Peleus: Studien zur Archäologie und Geschichte Griechenlands und Zyperns 6. Bibliopolis, Mannheim

Weiberg, E., and M. Finné, 2013. Mind or matter? People-environment interactions and the demise of Early Helladic II society in the northeastern Peloponnese. American Journal of Archaeology 117(1):1-31.

Weingarten, J., S. Macveagh Thorne, M. Prent, and J. H. Crouwel, 2011. More Early Helladic sealings from Geraki in Laconia, Greece. Oxford Journal of Archaeology 30(2):131-163.

Weiss, H., 2012. Quantifying collapse: The late third millennium Khabur Plains. In Seven Generations since the Fall of Akkad, edited by H. Weiss; pp. 1-24. Harrassowitz, Wiesbaden.

Weiss, H., 2013. The northern Levant during the Intermediate Bronze Age: Altered trajectories. In Oxford Handbook of the Archaeology of the Levant, edited by A. Killebrew, and M. Steiner; pp. 367-387. Oxford University Press, Oxford.

Weiss, H., and R. S. Bradley, 2001. What drives societal collapse? Science 291(5504):609-610.

Weiss, H., and M.-A. Courty, 1993. The genesis and collapse of the Akkadian Empire: The accidental refraction of historical law. In Akkad, the First World Empire, edited by M. Liverani; pp. 131-155. Springer-Verlag, Heidelberg.
Weiss, H., M.-A. Courty, W. Wellerstrom, F. Guichard, L. Senior, R. Meadow, and A. Currow, 1993. The genesis and collapse of third millennium north Mesopotamian civilization. Science 261(5124):995-1004.

Weninger, B., 2014. Archaeological and palaeoclimatological data to evaluate the potential impact of the $4.2 \mathrm{ka}$ calBP event in the Aegean and Southeast Europe. Paper presented at Tenth Annual University of Chicago Oriental Institute Seminar, The Early/Middle Bronze Age Transition in the Ancient Near East: Chronology, C14, and Climate Change, 7-8 March 2014, Chicago.

Wenxiang, W., and L. Tungsheng, 2004. Possible role of the "Holocene Event 3" on the collapse of Neolithic cultures around the Central Plain of China. Quaternary International 117(1):153-166.

Wiencke, M. H., 2000. Lerna: A Preclassical Site in the Argolid. Volume 4, The Architecture, Stratification, and Pottery of Lerna III. The American School of Classical Studies at Athens, Princeton.

Wiener, M. H., 2013. Realities of power: The Minoan thalassocracy in histori-

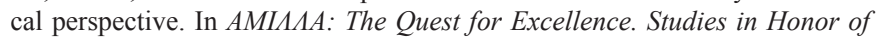
Guenter Kopcke, edited by R. Koehl; pp. 149-173. INSTAP Academic Press, Philadelphia.

Wiener, M. H., forthcoming. Oh, no- -Not another chronology! In The Art and Culture of Ancient Egypt: Studies in Honor of Dorothea Arnold, edited by A. Oppenheim, and O. Goelet. Bulletin of the Egyptological Seminar of New York 19.

Wilkinson, T. J., 1994. The structure and dynamics of dry-farming states in Upper Mesopotamia. Current Anthropology 35(5):483-520.

Wilson, D., 2008. Early Palatial Crete. In The Cambridge Companion to the Aegean Bronze Age, edited by C. W. Shelmerdine; pp. 77-104. Cambridge University Press, Cambridge.

Yancheva, G., N. R. Nowaczyk, J. Mingram, P. Dulski, G. Schettler, J. F. W. Negendank, J. Liu, D. M. Sigman, L. C. Peterson, and G. H. Haug, 2007. Influence of the intertropical convergence zone on the East Asian monsoon. Nature 445(7123):74-77.

Yasuda, Y., 2013. Decline of the Yangtze River civilization. In Water Civilization: From Yangtze to Khmer Civilizations, edited by Y. Yasuda; pp. 47-63. Advances in Asian Human-Environment Research. Springer Japan, Tokyo.

Yasur-Landau, A., 2010. The Philistines and Aegean Migration at the End of the Late Bronze Age. Cambridge University Press, Cambridge.

Yener, K. A., 1995. Early Bronze Age tin processing at Göltepe and Kestel, Turkey. In Civilizations of the Ancient Near East. Volume 3, edited by J. M. Sasson; pp. 1519-1521. Charles Scribner's Sons, New York.

Yener, K. A., and P. B. Vandiver, 1993a. Tin processing at Göltepe, an Early Bronze Age site in Anatolia. American Journal of Archaeology 97(2):207-238.

Yener, K. A., and P. B. Vandiver, 1993b. Reply to J.D. Muhly, "Early Bronze Age tin and the Taurus." American Journal of Archaeology 97(2):255-264.

Yoffee, N., 1988. The collapse of ancient Mesopotamian states and civilization. In The Collapse of Ancient States and Civilizations, edited by N. Yoffee, and G. Cowgill; pp. 44-68. University of Arizona Press, Tucson.

Yon, M., 2006. The City of Ugarit at Tell Ras Shamra. Eisenbrauns, Winona Lake, IN.

Zachos, K., and A. Dousougli, 2008. Observations on the Early Bronze Age sealings from the Cave of Zas at Naxos. In Horizon: A Colloquium on the Prehistory of the Cyclades, edited by N. Brodie, J. Doole, G. Gavalas, and C. Renfrew; pp. 85-96. McDonald Institute Monographs. McDonald Institute for Archaeological Research, Cambridge.

Zerefos, C. S., and E. C. Zerefos, 1978. Climatic change in Mycenaean Greece: A citation to Aristotle. Archiv für Meteorologie Geophysik und Bioklimatologie (Series B) 26:297-303.

Zwickel, W., 2012. Hungersnöte in der südlichen Levante vom 14. Jh. v. Chr. bis zum 1. Jh. n. Chr. In All the Wisdom of the East: Studies in Near Eastern Archaeology and History in Honor of Eliezer D. Oren, edited by M. Gruber, S. Ahituv, G. Lehmann, and Z. Talshir; pp. 453-466. Orbis Biblicus et Orientalis 255. Academic Press, Fribourg. 